\title{
What are Public Services Worth, and to Whom?* \\ Non-parametric Estimation of Capitalization in Pune
}

\author{
Somik V. Lall \\ World Bank and NIPFP \\ Mattias Lundberg \\ World Bank
}

\begin{abstract}
The availability and quality of basic public services are important determinants of urban quality of life. In many cities, rapid population growth and fiscal constraints are limiting the extent to which urban governments can keep up with increasing demand for these services. It therefore becomes important to prioritize provision of those services to best reflect local demand. We present a strategy to estimate the demand for public services, which is sensitive to heterogeneity in preferences across types of households, and the nonparametric estimation addresses problems arising from functional form restrictions. Using data from Pune, India, we estimate the demand for public services, as represented by the marginal change in the self-assessed monthly rental price of dwellings from the services. We find that the value of publicly provided services accruing to the poor is greater than that going to wealthier households, and even untargeted across-theboard investment in specific services can be progressive.
\end{abstract}

\section{JEL: H40; R21}

\section{World Bank Policy Research Working Paper 3924, May 2006}

The Policy Research Working Paper Series disseminates the findings of work in progress to encourage the exchange of ideas about development issues. An objective of the series is to get the findings out quickly, even if the presentations are less than fully polished. The papers carry the names of the authors and should be cited accordingly. The findings, interpretations, and conclusions expressed in this paper are entirely those of the authors. They do not necessarily represent the view of the World Bank, its Executive Directors, or the countries they represent. Policy Research Working Papers are available online at http:/lecon.worldbank.org.

\footnotetext{
* This paper is part of a larger effort to understand the contribution of urban public services to household welfare and overall quality of life. The research and data collection has been co-funded by a World Bank research grant on "Strengthening Fiscal Capacity of Indian Cities" and the UK DFID's Urban Knowledge Generation and Toolkits program. The authors can be contacted at slall1@worldbank.org (Lall) and mlundberg@worldbank.org (Lundberg).
} 


\section{$1 \quad$ Introduction: what are public services worth?}

The provision of public goods and services is the major function of governments, and governments have traditionally been the major providers and financers of services. Governments, particularly in developing countries are facing increased demand for services and greater responsibilities in the face of more rising financial constraints. This compels policymakers to set priorities, and to enhance the efficiency of service delivery. The World Development Report of 2004 (World Bank 2004) focused on the efficiency and management of public service delivery, emphasizing the importance of accountability and outcomes. That report provided new insights on the supply side; that is, how governments can improve service delivery. The demand side however has received less attention. One of main objectives in this paper is to examine the demand for services - the motivation comes from two disparate fields: first, the estimation of explicit reduced-form demand functions or demand systems, in which the quantity consumed is determined by prices and incomes; second, the work on capitalization and hedonic estimation of house prices.

We use a variant of the hedonic method to estimate the private returns to public services. That is, we estimate the change in house prices resulting from the provision of selected public services. This is implicitly a measure of the household's own subjective estimate of the value of public services. This paper focuses exclusively on the private value of public services. ${ }^{1}$ The services that we examine here are those that are important for improving a household's quality of life. These include access to piped water supply and sanitation, solid waste management, basic transport services, education, and crime

\footnotetext{
${ }^{1}$ We can't estimate the public value - the externalities - explicitly.
} 
prevention. Although the private willingness to pay may be an underestimate of the social benefits of improved service delivery, ${ }^{2}$ we believe that there will be many cases where the level of public service delivery is inadequate to meet even the private valuation of the benefits of improvements. Households may be willing to pay for improvements, but for a variety of reasons (coordination failure on both the demand and supply sides, institutional constraints), neither the public nor private sectors have risen to meet the demand.

\section{To Whom?}

It is well accepted that the distribution of public services is inequitable. The 2004 World Development Report reports that the poorest fifth of the population generally receives less than a fifth of public service expenditures, while the richest fifth receives more than one fifth of expenditure (World Bank 2004). In this view, the distribution of public services is inequitable because the value of public services provided to the wealthy is greater than the value of services provided to the poor. This claim is unarguable - if a public goal is to provide education, it is difficult to claim a priori that educating the wealthy is more expensive than educating the poor, to the same standard. But this view of distribution conflicts with a slightly different conception, in which distribution is defined relative to a particular index. This leads to the measurement of the concentration of the value of services at various points of (e.g.) the income distribution; and distribution of a good or service is considered progressive if it is more equitable than the prevailing distribution of income.

In this paper, we recover household-specific contribution of public services and other characteristics to the self-assessed rental price of a dwelling unit. We can then

\footnotetext{
${ }^{2}$ Availability of these services are likely to generate significant positive externalities.
} 
correlate these estimated values with a range of household characteristics, to understand how different households value different services. We can also use these results to compare the values of certain public services across households. Households can be ranked, for instance, by the self-reported rental values of their dwellings, and we can compare the distribution of various public services to the underlying distribution of housing capital. We find that although the wealthy certainly receive more of these public services, by value, the services accruing to the poorest is higher, when expressed as a share of the rental value of the dwelling unit.

\section{Valuing Public Services in Indian Cities}

With institutional and regulatory reforms emanating from the $74^{\text {th }}$ Constitutional Amendment Act (CAA 1992), more administrative and fiscal functions have been devolved to local authorities in India. ${ }^{3}$ Cities are now responsible for designing strategies to maintain and improve public services, and finding instruments to finance these activities in a sustainable manner. ${ }^{4}$ While supply side responses based on preset norms and standards are useful in setting priorities in terms of service provision, it is equally important to examine what services are demanded by local residents, as well as evaluate how they vary across different types of households, particularly the poor. In fact in December 2005, the Prime Minster launched the Jawaharlal Nehru National Urban Renewal Mission (JNNURM) to improve the contribution of cities to India's economic

\footnotetext{
${ }^{3}$ Mandatory provisions for devolution of fiscal and financial responsibilities and powers to city governments have been operational for more than a decade.

${ }^{4}$ In the decade since passage of these amendments, however, the effectiveness of decentralization has been limited, with slow and uneven progress across states. While the CAA envisioned decentralization of functions, finances and functionaries to enable Urban Local Bodies (ULBs) to function as "institutions of self government," in reality, fiscal and administrative decentralization have lagged behind political decentralization.
} 
development. One of the explicit objectives of the JNNURM is to ensure basic services to the urban poor, and an important strategy to do this would be to integrate the poor with service delivery systems. Presumably, these improvements are likely to improve the welfare of poor households.

However at this stage it is unclear what (package of) services are demanded by poor households, and whether pro-poor improvements should be targeted in the form of cash transfers / subsidies or if citywide improvements in services and public goods (such as extending water and sewer networks, reduction in crime and air pollution) are likely to accrue disproportionate benefits to poor households. In this paper, we outline a general methodology to assess the value of public services and apply this to examine demand for public services in the Indian city of Pune. While the empirical application focuses on household data collected for Pune, the estimation strategy outlined in the paper has broader applicability and can be used to examine similar issues across cities.

Our main finding is that the value of publicly-provided services accruing to the poor is greater than that going to wealthier households. ${ }^{5}$ The services examined (water, transport, education, safety) are worth roughly 29 percent of the rental value of the dwelling among the wealthy, but 67 percent of the rental value among the poor. The list of services examined in our analysis is clearly not comprehensive - wealthier households may benefit from different public services that we have not included. But the results suggest that even untargeted, across-the-board investment in these services can be progressive.

The remainder of this paper is organized into five sections. In Section 2, we discuss the role of hedonic models in estimating the net benefits from local property taxes 
and public services. Section 3 describes the data, and Section 4 discusses our model. And estimation strategy, Section 5 provides the main findings and Section 6 concludes.

\section{Hedonics, property taxes, and public services}

Hedonic estimation is based on the principle that goods can be described as a bundle of attributes and the value of a good is a combination of the values of these attributes (Lancaster 1966; Rosen 1974). This implies that the value of a dwelling unit is a function of the value of its physical characteristics (such as size), as well as the characteristics of its neighborhood and the services and amenities available in the area. By extension, the present value of a dwelling is the discounted stream of future net benefits that are expected to accrue to the occupant or owner.

The idea that the present value of a dwelling is the sum of benefits derived from it is formally described as capitalization. This has been used extensively to study variation in housing prices and location decisions. For example, the bid-rent models of Alonso (1964), Muth (1969) and others were based on the observation that land values decline with distance from (monocentric) city centers, as the cost of commuting increases, and that this variation is reflected in the price of housing.

In hedonic models, households choose dwellings as different bundles of amenities. In Tiebout's (1956) original paper, households vote with their feet, sorting into communities based on their preferred levels of public good provision. Tiebout found that local jurisdictions compete with each other to attract residents on the basis of service provision. Tiebout's model did not include property taxes; Oates (1969) expanded the

\footnotetext{
${ }^{5}$ Values are expressed in terms of the price of housing or income.
} 
model to include tax payments, to test the hypothesis that households choose locations based on the combinations of taxes and services.

In this "benefit view" of local tax and service, the value of public services (and concomitant taxes) is capitalized into the price of housing. In equilibrium, the additional value of public services in housing is zero: services are exactly offset by taxes. The value added by public services to the price of housing is net of property taxes paid. Thus, in principle, the value added from public services is a transfer from the public sector to the property owner or resident. This value added can in principle be extracted from the household in local taxes, and jurisdictions choose the combination of taxes and services to attract and retain residents.

Fischel (2000) presents a more modern variant of the Tiebout model, in which the median voter (the "homevoter") will elect a local government that provides the optimum combination of local taxes and services to maximize local property values. The government's objective includes the desire to remain in office and the need to prevent households from migrating to other districts.

Tiebout's model and its successors are partly based on the assumption that the supply of housing is fixed, at least in the short run. If not, increased demand due to preferable bundles of services in certain areas would engender a supply response, bidding down property values.

This importance of this assumption is minimized, but not altogether eliminated, in the "new view" of local taxation, which allows the stock of residential capital to move (or rather to be converted to other uses). In this view, increased taxes will encourage the capital stock to move. The two views are not necessarily contradictory. In the short run, 
residential capital is more or less immobile. In the medium and long run, taxes may prompt capital to move, as well as residents.

The question remains whether property taxes are a fee for public services (in the benefit view) or a distorting tax on capital (in the new view). In principle, the former model predicts that higher taxes will lead to increased property values; whereas in the latter, higher taxes lead to a fall in property values. But the distinction is not so clear. Oates (1969) argues that an increase in taxes without a commensurate increase in services leads to a decline in property values, but if accompanied by an increase in local expenditures, then a tax increase might lead to an increase in property values.

Research has consistently shown that capitalization does occur. But not all local expenditure and taxes are capitalized into property values, and the elasticity of capitalization is generally less than one - that is, a one percent increase in local expenditure yields a less-than-one percent increase in property prices. This may be because the increases are transitory, or that it is the rate of change in local services that matter, rather than levels. In addition, local public services are by definition (or at least by assumption) public goods, with significant externalities. The benefits from these public goods can accrue to those who pay neither taxes nor rents, and perhaps even to those who do not reside in the jurisdiction.

In addition to the costs and benefits of commuting and public services, individuals have preferences over community composition. This is most famously articulated in the works of Thomas Schelling $(1969,1971,1978)$ whose models of social interaction show that microeconomic forces such as discriminatory individual preferences or behavior lead to aggregate phenomena such as sorting and segregation. This model implies that people 
are willing to pay differential premiums to live near others who share common socioeconomic or demographic characteristics. These characteristics include religion, class, language, educational attainment, and duration of stay and tenure in the city.

\section{Data}

Our data come from Pune, a city located in the State of Maharashtra, approximately 200 kilometers east of Mumbai. Pune has a population of 2.8 million, of whom close to one million live in slum settlements distributed throughout the city (Bapat and Agarwal 2003). The empirical analysis draws on a household survey which was collected between August and October 2002, and designed to be representative of the Pune Municipal Corporation area. All households of the city are part of the sampling universe, with the exception of residents of military cantonments and institutional populations (e.g. prisons). The sample was chosen to be representative of each of the 48 wards (administrative units) in proportion to the preliminary estimates of the Census of March 2001. For our survey, 2850 households were randomly selected and asked questions regarding socioeconomic characteristics, quality and quantity of housing, tenure status, and access to infrastructure services. Non-response and other missing data problems reduce the size of the dataset for analysis to 2703 households.

The value of the dwelling unit is the household's willingness to pay (WTP) for a set of dwelling unit and neighborhood characteristics. The survey asked each household the following questions: "What would be the estimated present market price for a similar unit in this neighborhood?" and "What would be the estimated monthly rental value for a similar unit in this neighborhood?" We use the latter measure in the empirical work 
below. A summary of self-assessed monthly rents is provided in Appendix Table 1A and $1 \mathrm{~B}$, as well as the dwelling-unit and household characteristics used in the estimation.

We distinguish three types of characteristics that can influence the self-assessed value of housing. First are the attributes of the dwelling unit itself. These include mains water and sewer, the distance to the nearest bus stop, whether the dwelling is detached or attached (relative to apartment), living space, whether the dwelling has a good roof and good exterior, and whether the dwelling is in a slum.

Second, we include a set of variables describing the characteristics of the neighborhood. These are mostly defined as the characteristics of the nearest 25 sample neighbors, and include the share of detached houses, the share of attached houses, mean living space, the share with good roof and good exterior, the share of neighbors in slums, the number of parks and schools within $1 \mathrm{~km}$, and the mean effective property tax rate of neighbors. ${ }^{6}$ We also include a measure of housing density - the number of dwellings in the ward - as a measure of the supply constraints in the housing market. The tax- and service-capitalization models assume that zoning and other restrictions constrain the supply of housing, forcing residents to move in response to changes in policy. The incentive to move, and indeed the incentive for jurisdictions to compete, is diminished with more elastic supply.

Finally, we include a set of variables describing the characteristics of the neighbors. These are also defined for each dwelling as the mean values of the nearest 25 neighbors, and include the share who are scheduled caste, mean years of residence, the share of household heads with higher education, mean income from durables and the

\footnotetext{
${ }^{6}$ This is the actual tax paid, plus other (unspecified) fees, as a percentage of the stated value of the dwelling, including those who report paying no taxes; not the official tax rate.
} 
mean log deviation of durables income, the share of neighbors who own their residence, the share who feel the neighborhood is safe, the share who feel roads are dangerous, and the share who feel air is severely polluted.

Each of these categories contains a subset of variables that indicate the provision of public services. Of the dwelling unit characteristics, mains water and sewer, and the distance to the nearest bus stop, are amenable to policy; whereas the others reflect decisions either of builders or the households themselves. While every household in the city gets access to water using alternate sources, we focus on the capitalization effects of networked or piped water supply. In Pune, the municipal corporation (PMC) is responsible for providing water within the city limits. Our survey data however suggest that piped or networked supply coverage is not universal. Only 55 percent of surveyed households report receiving piped water directly from the PMC water network. Another 21 percent receive piped water by (illegally) sub connecting to households who have official access to the piped network. Other water sources include private mini water systems, handpumps, tubewells, community taps, and water tankers. Given the considerable variation in access to water, having a piped or network connection should make the dwelling unit more attractive than comparable units without piped access.

Of the neighborhood variables, the variables that reflect policy are the number of parks and schools within $1 \mathrm{~km}$, and the mean property tax rate of neighbors. We include the opinions of neighbors to crime, road safety, and air pollution as indicators of policy. While these attitudes may not accurately reflect the actual state of crime, road safety and pollution, it is plausible that house prices are more likely to reflect attitudes rather than statistics. These attitudes are likely formed by a combination of the municipal 
government's actions to alleviate these problems, as well as the public information campaigns to assuage the fears of residents.

In our estimation, we include both renters and owners, since they will both benefit from public services, and since the value of public services may be capitalized in the rental value of property as well. Owners and renters can both value schools and hospitals. Similarly, we use the mean tax payments (including zeros) of all households in a neighborhood, rather than dwelling-specific payments. To the extent to which local services are directly supported by local tax payments, the taxes paid by neighbors have significant external effects. This minimizes the impact of measurement error in reported tax payments, and allows us to include renters as well as owners in the sample. ${ }^{7}$

One of our goals in this paper is to understand the variance in the demand for and willingness-to-pay for certain public services. We expect that demand for various housing and neighborhood attributes is significantly heterogeneous: it varies systematically with household characteristics. We estimate differences in the value of housing characteristics as a function of a set of household characteristics, including the age and education of the household head, whether the household head was born in Pune, whether the household is scheduled caste (a marginalized category in the social system), the number of years the household has lived in its current dwelling, the household's income from durable goods, and whether the household owns the dwelling. This allows us to estimate the value of different public services across groups of households.

\footnotetext{
${ }^{7}$ We ignore the taxes passed through to renters by property owners in the form of higher rents.
} 


\section{Model and Estimation Strategy}

The simple hedonic method discussed above is a reduced form. Under certain maintained hypotheses (such as perfectly elastic supply), single-equation hedonic parameter estimates can have a structural interpretation. But these assumptions are generally untenable (Malpezzi 2002). ${ }^{8}$ This has led researchers to develop two-stage models, in which the second stage is an attempt to recover structural demand parameters for individual housing characteristics. The second stage is usually estimated independently for individual dwelling unit characteristics, such as living space, as functions of demand shifters such as household characteristics.

Malpezzi (2002) points out the key role of functional form in estimating hedonic equations; most two-stage hedonic estimators are in fact identified by the assumptions implicit in choice of functional form - for example by the differences between logarithmic first-stage and linear second-stage regressions. The obtained estimates are thus reliant on the choice of functional forms.

In this paper we use a variant of the three-stage method of Bajari and Kahn (2003) to recover structural demand parameters, and explain these tastes as functions of household characteristics. We avoid the problems of functional form in two ways. First, we estimate a nonparametric first stage, using general additive modelling techniques. Second, we bootstrap, so that the final reported estimates are the result of 250 repetitions of the method.

\footnotetext{
${ }^{8}$ Chay and Greenstone (2005) review econometric problems in hedonic models, and they suggest that in single equation cross-section models, misspecification frequently occurs which leads to inconsistent estimates of hedonic prices and thus inconsistent marginal willingness to pay estimates. Omitted variables may bias estimates if there are unobserved factors that vary, for both with housing prices and service levels. This may be less of a problem where rich information is available at the individual observation level, compared to applications such as Chay and Greenstone (2005) that use a very limited set of highly aggregated variables.
} 
Following Bajari and Kahn, we assume that the household gets utility from consumption of housing and other goods and services:

$$
u_{i j}=u\left(x_{j}, \eta_{j}, c\right)
$$

where $u_{i j}=$ utility of household $i$ from $\operatorname{good} j ; x_{j}=\operatorname{observed}$ characteristic of $\operatorname{good} j ; \eta_{j}=$ unobserved characteristic of good $j ; c=$ Hicksian composite good, with price normalized to one. Price is a function of observed and unobserved characteristics $p_{j}=p\left(x_{j}, \eta_{j}\right)$. Letting $y_{i}=$ income, and substituting for $c=y-p\left(x_{j}, \eta_{j}\right)$, we can solve for the consumer's utility-maximising product bundle $j^{*}(i)$ :

$$
\begin{aligned}
& \frac{\frac{\partial u_{i}\left(x_{j^{*}}, \eta_{j^{*}}, y_{i}-p_{j^{*}}\right)}{\partial x_{j, k}}}{\frac{\partial u_{i}\left(x_{j^{*}}, \eta_{j^{*}}, y_{i}-p_{j^{*}}\right)}{\partial c}}=\frac{\partial p\left(x_{j^{*}}, \eta_{j^{*}}\right)}{\partial x_{j, k}} \\
& \frac{\beta_{i k}}{x_{j^{*} k}}=\frac{\partial p\left(x_{j^{*}}, \eta_{j^{*}}\right)}{\partial x_{j, k}}
\end{aligned}
$$

In other words, the marginal rate of substitution between a (continuous) characteristic and the composite $c$ is the partial derivative of the hedonic. Following Bajari and Kahn (2003) and Bajari and Benkard (2002), we place some restrictions on the utility function for identification of the derivative

$$
u_{i j}=\ln \left(x_{j}\right) \beta_{i j}+\beta_{i \eta} \ln \left(\eta_{j}\right)+c
$$

so that we can recover the utility function parameters $\beta$ :

where $\frac{\partial p\left(x_{j^{*}}, \eta_{j^{*}}\right)}{\partial x_{j, k}}$ is estimated by the first-stage hedonic.

$$
\begin{gathered}
\beta_{i k}=x_{j^{*} k} \frac{\partial p\left(x_{j^{*}}, \eta_{j^{*}}\right)}{\partial x_{j, k}} \\
\text { the first-stage hedonic. }
\end{gathered}
$$


In the third stage, we allow the housing demand parameters to be heterogeneous, such that

$$
\beta_{i k}=f_{k}\left(z_{i}\right)+\varepsilon_{i k}
$$

where $z_{i}$ is a vector of demand-shifting household characteristics.

\subsection{Estimation strategy}

Following Bajari and Kahn (2003), our estimation proceeds in three steps. First, we estimate the non-parametric hedonic function. Second, we recover the structural demand parameters using the first-order conditions described in (2). Third, we estimate the determinants of these demand parameters on a vector of household characteristics. We depart from Bajari and Kahn in two main ways: we employ a different method for the estimation of the hedonic, and primarily to ensure robustness, we bootstrap each stage 250 times.

\section{Nonparametric hedonic estimation}

As Malpezzi (2002) and others have mentioned, hedonic estimates have been driven by functional form assumptions. The "wrong" functional form can have terrible consequences for traditional estimators (Pace 1998). In response, researchers have tried a variety of nonparametric and semiparametric methods (see Pace 1995, 1998 for nonparametric estimation; Anglin and Gencay 1993 for semiparametric estimation), which have been shown to outperform OLS estimators.

Nonparametric estimation is also useful when the partial relationship between the regressors and the dependent variable is significantly nonlinear. If the nonlinearity is simple and monotone, the variables may be transformed, for example by using logs, 
powers, or polynomials. But some of these transformations (such as the flexible TransLog), are undefined if attributes take zero values. ${ }^{9}$

Nonparametric methods are preferable to ad hoc methods for addressing nonlinearity, but the most commonly used nonparametric methods present a different set of problems. Locally weighted regressions depend to a large degree on the smoothing parameter (the kernel) and the bandwidth. There is no robust method for choosing these values a priori; the choice is often based on visual inspection of the data and the results. When extended to the multivariate case, local multivariate regressions quickly suffer the “curse of dimensionality:" as the number of regressors increases, the number of observations in each multidimensional neighborhood gets smaller. The solution is to increase the size of the span or window to capture more observations, but doing so quickly makes the regression less local, and the bias due to unspecified nonlinearity quickly returns.

The general additive regression models (GAM) overcome the problem of dimensionality by applying local regression to low dimensional projections of the data (Hastie and Tibshirani (1995). The GAM can be described as

$$
E\left(y_{i}\right)=\alpha+f_{1}\left(x_{1 i}\right)+f_{2}\left(x_{2 i}\right)+\ldots+\varepsilon_{i}
$$

where the functions $f($.$) are determined empirically. { }^{10}$ The model is solved by "backfitting" and iteratively reweighted least squares, minimizing the sum of squared errors from (6) until convergence. The data are first recast in deviations from the mean, so that the partial regressions sum to zero. We obtain preliminary estimates from an OLS regression of $y$ on $x$, and then compute the partial residuals for each $x_{m}$ which are

\footnotetext{
9 Taking the log of a variable after adding one causes little trouble if the values are "large", but causes problems if the variable is small, such as a proportion (bounded by zero and one).
} 
orthogonal to the expectation of $y$ given $x_{\forall n \neq m}$ (see Hastie and Tibshirani 1990, Andersen 2004 for detailed explanations). The GAM essentially reduces the problem of estimating nonparametric regressions to a sequence of bivariate smoothing problems. This also allows us to make simple plots showing the bivariate partial relationships between each $x_{m}$ and $y$. These are presented as Appendix Figures A1-A21.

Pace (1998) presents GAM estimates of prices and housing characteristics on a sample of 442 houses with transactions data from Memphis, Tennessee. He finds that the GAM estimator consistently outperforms the OLS estimator in a variety of functional forms, obtaining a better overall fit and much less bias. The purpose of that paper is primarily to compare results across estimators, and does not attempt to derive structural demand parameters. Although we share the same first-stage estimation method as Pace, this paper is closer in spirit to that of Bajari and Kahn (2003).

\section{Recovering structural parameters}

The restrictions placed on the utility function (3) allow us to obtain closed-form solutions to for the first order conditions (4) for continuous variables. Our model of housing demand includes both continuous and categorical variables, and the derivation method must account for this distinction. For continuous characteristics, we follow Bajari and Kahn, and define the derivative as

$$
\hat{\beta}_{k}=x_{j^{*} k} \hat{\gamma}_{k}
$$

where $\hat{\gamma}_{k}=\frac{\partial p\left(x_{j^{*}}, \eta_{j^{*}}\right)}{\partial x_{j, k}}$. In this way, the value of the characteristic is allowed to vary across households. For dichotomous characteristics, we must use a different method. As Bajari and Kahn point out, for dichotomous variables, there will be no first-order

\footnotetext{
${ }^{10}$ Note that the linear (OLS) regression is a case of GAM with infinite smoothing.
} 
condition. Instead, utility maximization implies a threshold decision rule. Households for which the price of a dichotomous characteristic exceeds the utility derived from having it will choose not to have it; and those in which the utility exceeds the price will choose to have it. We derive the implicit value of the dichotomous characteristics using Kennedy's approximation:

$$
\hat{\beta}_{k}=\exp \left(\hat{\gamma}_{k}-\frac{1}{2} \hat{V}\left(\hat{\gamma}_{k}\right)\right)-1
$$

where $\hat{V}\left(\hat{\gamma}_{k}\right)$ is an estimate of the variance of $\hat{\gamma}$.

\section{Heterogeneity of tastes and demand}

In the third stage, we regress the derived structural demand parameters against a vector of household characteristics. Here we follow Bajari and Kahn (2003), estimating demand (willingness to pay) for continuous variables as OLS, and for dichotomous characteristics as maximum likelihood probit, normalizing the coefficient on price equal to -1 .

\section{Main Findings}

\section{Stage 1 and 2 results}

Here we discuss the results of each stage in turn. First, we highlight two of the smoothed partial plots derived from the GAM hedonic regression, to show that the relationship between some of the variables of interest and monthly rent is neither simple nor monotonic. For example, Figures 1A and 1B show the partial residual plot of the distance to the nearest bus stop and the number of schools, respectively. These figures show considerable nonlinearity in the relationship between these services and rent. Holding other characteristics constant, households that live closer to bus stops are willing 
to pay more (relative to the mean) for their dwellings, and households that live further away are willing to pay less. Dwellings with access to more schools command a significantly higher price than those with fewer schools.

Table 1 presents selected results from the GAM estimation, including only those variables that explicitly represent public services. ${ }^{11}$ Results for the extended set of variables used in the estimation are reported in Appendix Tables 1B and 2. In terms of the implicit values, the dwelling unit's living space and having a good exterior add the most to the rental value of a property.

Our discussion however focuses on public services and local amenities, which are reported in Table 1. This table shows that on average, a few public services are significantly capitalized into the rental price of the property. A connection to the mains water supply adds 160 Rupees, or about 14 percent, to the rental value of a property. On average, access to schools is worth about 120 Rupees, or about 10 percent, to the rent. None of the neighbor characteristics is significant, on average.

It is important to note here that the fact that these estimates are insignificant on average does not mean that they are insignificant to all households. Even without considering taste shifters and other covariates, a quick glance at Figures 1A and 1B reveals that public transport and the availability of schools matters more to some households than others. Households differ considerably in their subjective evaluation of these characteristics, as the next section will show.

Table 1 also presents a measure of the "gain" from the nonlinear estimation method. Hastie and Tibshirani (1995) consider this a relatively imprecise measure of the value of the GAM estimates, but we can have some confidence in the result, since it is 
derived from the bootstrapped estimates. This is a chi-square approximation to the distribution of the gain relative to the linear marginal relationship between the independent and dependent variables, and is rejected in 100 percent of the bootstrapped estimates, indicating that the relationships are significantly nonlinear.

\section{$3^{\text {rd }}$-stage simulations}

In order to understand the diverse preferences for dwelling unit attributes, we regress the structural utility estimates derived using the first-order conditions in (7) and (8) on a range of household characteristics. For the dichotomous variables, we follow Bajari and Kahn and estimate a probit regression on a dummy variable indicating possession of the attribute, while constraining the parameter on the price (obtained in the GAM) to -1 . For the continuous variables, we run simple linear regressions on the rental value of an improvement in the attribute of one-half of one standard deviation around the mean. Table 2 shows the magnitudes of these changes. For the dichotomous attributes (mains water, sewer), the value of the improvement is clearly 100 percent of the value of the attribute. For the continuous variables, the simulated changes range from a seven percent improvement (ie a decline) in the share of neighbors who feel air is severely polluted, to a 100 percent increase in the number of parks within one kilometer. The range is large, since the changes are defined by the distribution of the underlying variables.

Other things being equal, the value of the tax in the price of housing is an indicator of the net benefit of local taxes and services to the local residents. A negative value would indicate that the net benefit of the tax and local services is negative; the tax

\footnotetext{
${ }^{11}$ These are the means of the bootstrapped parameter estimates and variances.
} 
is considered a burden, and lowers the value of a property, in principle to the extent of the present value of the discounted stream of anticipated tax payments. If the value of the tax payment is positive, it suggests that households value the local services provided by the municipal government, and possibly that the household understands that the provision of local services is somehow connected to the payment of local taxes.

The results in Table 2 provide prima facie support for the benefit view of local taxes. A 40 percent increase in the tax rate will on average increase the rental value of the property by 11 Rupees, or about 1.3 percent. The median house price in Pune is Rs.200,000, and the median rent is Rs.1000, implying a roughly 5 or 6 percent annual return on investment, ${ }^{12}$ which is considerably lower than current (July 2005) Indian mortgage interest rates of around 10 percent. The mean tax rate is 0.7 percent of the purchase price. At a discount rate of 5 percent, the net present value of tax payments is about 1.2 percent of the purchase price, implying an elasticity of house prices with respect to taxes of about 1.5. At a ten percent discount rate, the elasticity of house prices to tax rates is about 0.8 . These are rather high tax capitalization rates, relative to those found in the US, of around 0.6. Even so, these estimates support the view that on average, households value the benefits they receive in return for payment of local taxes.

These averages mask significant variation across households. In the third stage, we regress the individual willingness-to-pay measures derived from the GAM results on a parsimonious set of household characteristics. Selected results from these regressions are presented in Tables 3.1 to 3.3 .

Table 3.1 presents the results for dwelling unit attributes. In all cases, the value of services varies across wealth: wealthier households will pay more for services than 
poorer households. But other characteristics matter, as well. On average, the value of a mains water connection adds 160 Rupees to the monthly rent of a dwelling. Among scheduled caste households (holding other household characteristics constant), the value of the mains water connection is about ten Rupees less than average. The scheduledcaste household is still willing to pay for the mains connection, but it will not pay as much as an average household for the service. Households with older heads will pay more, as will households that are native to Pune, and households that have been resident longer in their dwellings will also pay more for mains water. Consistent with the predictions of capitalization, owners will pay about 50 percent more than average for mains water connection.

Connection to the sewer is worth significantly less on average than mains water connection. ${ }^{13}$ Sewer connections are relatively more valuable to households with educated heads, and to those native to Pune. Surprisingly, owners of dwellings value sewer connections less than renters.

The simulation on the nearest bus stop is expressed as a decrease in the distance (a good) so that we can examine the household's positive willingness to pay. On average, a 40 percent decrease in the distance to the bus stop is worth about 23 Rupees per month. To scheduled-caste households, this improvement may be worth only 17 Rupees (though the parameter estimate in the third stage is not significant). To households with educated heads, the improvement is worth 50 Rupees. Owners and wealthier households are also willing to pay more for a decrease in the distance to the

\footnotetext{
${ }^{12}$ Net of transactions costs, and assuming house prices do not change.

${ }^{13}$ This lower estimate of the benefits to sewers is not due to correlation between mains water and sewer. Although households with one are more likely to have the other, the simple correlation between them is 0.1 .
} 
bus. Note that this does not imply that the wealthy are more likely to use public transport.

Table 3.2 looks at the value in terms of monthly rent of changes in neighborhood attributes. The mean results showed that on average, monthly rents were unrelated to the number of parks within one kilometer. This holds true for different types of households, as well. The second column examines differences in the value of access to schools. This is a measure of all facilities, regardless of level or management (i.e., it is the count of all schools, public and private, primary schools to technical colleges). On average, the number of schools is worth 120 Rupees per month. Among scheduled caste households, access to schools is worth 85 Rupees. However, we find that households with moreeducated heads value schools much more than average - among these households, access to schools is worth 205 Rupees per month. Similarly, households with older heads value schools more than average, but not by much.

The final column in Table 3.2 looks at the value of tax rates, as expressed in the self-assessed rental value of housing. This is the mean tax rate in the neighborhood, rather than the actual tax rate facing the household. Although the tax is paid exclusively by owners, it is likely that the cost of taxes is passed through to renters, as well.

Wealthier households are willing to pay more to live in an area with higher mean tax rates, as are owners. In principle, areas with more owners will have a higher mean tax rate than areas with a larger proportion of renters, since the latter pay zero taxes. This result does not reflect the value of living in an area with many owners relative to an area with many renters, since we control for the proportion of owners in the first stage - so the 
results presented here more properly reflect the self-assessed value of tax payments specifically.

Table 3.3 presents the results of regressions on the value of the characteristics of the neighborhood as reflected in the attitudes of neighbors. Although on average, none of these attributes is significantly related to the rental price of a dwelling, there is considerable variation across households. Scheduled caste households are willing to pay less than average for both criminal safety and a clean environment. Older household heads will pay more, as will households with educated heads, and owners. In particular, households where the head has high school or higher education are willing to pay Rs. 149 for safety and Rs. 131 for a cleaner environment.

These results suggest that the benefits of improvements in municipal public services and amenities generally accrue to wealthier households. This is true, in terms of absolute value. But if we express the value of the services in terms of the rental value of the dwelling (or of income - the results are consistent), we see that the relative distribution of public services is pro-poor and pro-scheduled caste. Table 4 presents the value of the simulated improvement in services as a percentage of self-assessed rent.

The first two columns of Table 4 compare the relative benefits of these simulated interventions across wealth class. In all cases, the relative benefits to the poorest quartile are greater than those accruing to the wealthiest quartile. A connection to the mains water is four times more valuable to the poor; sewers, distance to bus, safety, air pollution, are all worth twice as much to the poor.

The second two columns compare scheduled-caste and non-scheduled caste households. Here the distinction is not so great, but these untargeted interventions seem 
to benefit scheduled-caste households more than non-scheduled caste households. The third pair of columns compares the relative benefits accruing to native-born and immigrant households; there is little difference between the two. ${ }^{14}$

The final pair of columns compares the returns to households that own their dwellings with those that do not own their dwellings. Ownership in Pune can be de facto as well as de jure, and does not necessarily imply possession of legally sanctioned title. Ownership is therefore not strictly correlated with income or even wealth. Many poor households, including those in slums, own their dwellings, whereas many middle-class households rent flats. These columns show little differences between owners and renters, with two exceptions. The first is that owners value mains water connection more than renters. The second is that owners are willing to pay more than renters to live in areas with higher average tax rates, and that this increase is not entirely passed through to renters. This makes sense, since it is owners who benefit from capitalization, whereas both owners and renters benefit from the provision of public services.

\section{Discussion}

The main objective of our paper is to estimate the demand for public services and amenities, and examine if and how demand for specific services varies across groups of households. For example, is the demand for networked or piped water and sewerage higher for poorer households? Or are safety from crime and violence and air quality more important for the highly educated? Understanding local demand and preferences is important as the provision of public services and amenities should reflect local

\footnotetext{
${ }^{14}$ Roughly $1 / 3$ of households in the sample are scheduled caste, and $2 / 3$ are native to Pune.
} 
preferences and local governments need to prioritize public expenditures in times of fiscal stress.

To examine heterogeneous demand for public services, we estimate a nonparametric hedonic function and allow the structural demand parameters to vary with household characteristics. The value of public services and other dwelling unit attributes are recovered non-parametrically, without resorting to restrictive functional forms. In fact, linear or even systematically (e.g., logarithmic or exponentiated) parametric nonlinear forms may be significantly biased: the $\chi^{2}$ test of linearity in parameters is rejected in 100 percent of the bootstrapped samples. For robustness, we re-ran the regressions and simulations in OLS (results available). The OLS first-stage regression had consistently smaller - and most likely underestimated - standard errors. Conversely, because we do not impose parametric restrictions on the $1^{\text {st }}$ stage, we achieved a much better fit in the $3^{\text {rd }}$-stage regressions using the GAM estimates. The OLS $3^{\text {rd }}$-stage parameter estimates were on average one-third smaller than the GAM estimates, and a quarter of them also had different signs.

Housing stock comprises large fraction of wealth, and housing services are a substantial part of consumption. Households place great value on certain attributes: living space, public services, housing quality, neighborhood attributes, and so on. The value of these attributes differs significantly among households, by wealth, education, social status (caste), and other characteristics. Although wealthier households receive a greater share of value of public services (water, transport, education, safety), poorer households also benefit. And when expressed in terms of the price of housing or income, the value of publicly-provided services accruing to the poor is greater than that going to 
wealthier households. The services examined here are worth roughly 29 percent of the rental value of the dwelling among the wealthy, but 67 percent of the rental value among the poor. The list of services examined here is clearly not comprehensive - wealthier households may benefit from different public services that we have not included. But the results suggest that even untargeted, across-the-board investment in these services can be progressive.

The methodology used here can be applied broadly to examine the demand for housing and public services across cities. While the analysis here is limited to short-term capitalization effects where residential capital and households are relatively immobile, it will be useful to extend this approach to evaluate long-term implications of service delivery failures when both households and capital can move to alternate locations in response to supply side failures. This would provide complementary evidence to highlight the impact of public service provision on urban performance. 


\section{References}

Andersen, R, 2004. "Nonparametric Regression and Generalized Additive Models." York University, Summer Program on Data Analysis (SPIDA).

Anglin, P. M. and R. Gencay, 1993. "Semiparametric Estimation of a Hedonic Price Function." Windsor: University of Windsor.

Bajari, P. and M. E. Kahn. 2003. Estimating Housing Demand with an Application to Explaining Racial Segregation in Cities. NBER Working Paper . 9891. National Bureau of Economic Research: Cambridge, MA.

Bapat, M. and I. Agarwal. 2003. Our needs, our priorities; women and men from the 'slums' in Mumbai and Pune talk about their needs for water and sanitation. Environment and Urbanization, 15, 2, 71-86.

Chay, K. Y. and M. Greenstone. 2005. "Does air quality matter? Evidence from the housing market." Journal of Political Economy 113. (2): 376-424.

Fischel, W. 2001. The Homevoter Hypothesis: How Home Values Influence Local Government Taxation, School Finance, and Land Use Policies. Cambridge: Harvard University Press.

Hastie, T. and R. Tibshirani, 1990. Generalized Additive Models. Chapman and Hall. and , 1995. "Generalized Additive Models.” Department of Statistics and Division of Biostatistics, Stanford University, 12th May, 1995.

Kennedy, P. 1981. "Estimation with Correctly Interpreted Dummy Variables in Semilogarithmic Equations," American Economic Review 71:4:801.

Lancaster, K. J. 1966. “A New Approach to Consumer Theory,” Journal of Political Economy 74, pp. 132-157.

Muth, R. F. 1969. Cities and Housing: The Spatial Pattern of Urban Residential Land Use. Chicago: University of Chicago Press.

Malpezzi, S. 2002. Hedonic Pricing Models: A selective and applied review, Gibb, K and A. O’Sullivan eds Housing Economics, Blackwell Science, UK.

Nechyba, T. 2000. “The Benefit View and the New View: Where Do We Stand After 25 Years into the Debate?" Presented at the conference on Property Taxation and Local Government Finance, Lincoln Land Institute. 
Oates, W. 1969. “The Effects of Property Taxes and Local Public Spending on Property Values: an Empirical Study of Tax Capitalization and the Tiebout Hypothesis.” Journal of Political Economy 77:957-71.

Pace, R. K. 1998. “Appraisal Using Generalized Additive Models,” Journal of Real Estate Research 15:1/2:77-99.

— 1995. "Parametric, Semiparametric, and Nonparametric Estimation of Characteristic Values Within Mass Assessment and Hedonic Pricing Models," Journal of Real Estate Finance and Economics 11:195-17.

Roback, J. 1982. "Wages, Rents, and the Quality of Life," Journal of Political Economy 90 (December 1982), 1257-1278.

Rosen, S. 1974. "Hedonic Prices and Implicit Markets: Product Differentiation in Pure Competition." Journal of Political Economy 82:1:34-55.

Rosen, S. 1979. "Wage-Based Indexes and the Quality of Life" (pp. 74-104), in P. Mieszkowski and M. Straszheim (Eds.), Current Issues in Urban Economics (Baltimore: Johns Hopkins University

Schelling, T. C. 1969. "Models of Segregation.” American Economic Review, 59, 2: 48893.

Schelling, T. C. 1971. "Dynamic Models of Segregation”. Journal of Mathematical Sociology, 1:143-186.

Schelling, T. C. 1978. Micromotives and Macrobehavior, Norton: New York.Tiebout, C. 1956. A Pure Theory of Local Expenditures, Journal of Political Economy, 64: 416-424.

United Nations. 2000. World Urbanization Prospects, The 1999 Revision.

World Bank, 2004. World Development Report: Making Services Work. 
Table 1. GAM results, first-stage hedonic estimates ${ }^{6,7}$

\begin{tabular}{|c|c|c|c|c|}
\hline $\begin{array}{l}\text { Dependent variable: log of estimated } \\
\text { monthly rental value } \\
\text { Own dwelling characteristics }\end{array}$ & \multicolumn{2}{|c|}{$\begin{array}{c}\text { First stage hedonic } \\
\text { estimates }^{3}\end{array}$} & \multicolumn{2}{|c|}{$\begin{array}{l}\text { Implicit mean value of } \\
\text { attribute (Rupees) } \\
\text { 3,4,5 }\end{array}$} \\
\hline Mains water ${ }^{1}$ & 0.129 & $(0.04) * *$ & 161.519 & $(53.84)$ \\
\hline Sewer ${ }^{1}$ & 0.062 & $(0.05)$ & 76.061 & $(64.81)$ \\
\hline Distance to bus ${ }^{2}$ & -0.006 & $(0.00)+$ & -61.260 & $(31.89)$ \\
\hline \multicolumn{5}{|l|}{ Neighborhood characteristics ${ }^{2}$} \\
\hline Parks within 1 km & 0.000 & $(0.00)$ & -4.519 & $(18.38)$ \\
\hline Schools within 1 km & 0.005 & $(0.00) *$ & 122.223 & $(81.00)$ \\
\hline Property tax rate $(\%)$ & 0.028 & $(0.04)$ & 29.056 & $(43.67)$ \\
\hline \multicolumn{5}{|l|}{ Neighbor attitudes ${ }^{2}$} \\
\hline Share who feel neighborhood is safe & 0.198 & $(0.13)$ & 260.492 & $(193.10)$ \\
\hline Share who feel air pollution is severe & -0.161 & $(0.22)$ & -227.666 & $(339.58)$ \\
\hline
\end{tabular}

Notes:

${ }^{1}$ Dummy variables.

${ }^{2}$ Continuous variables.

${ }^{3}$ Standard error in parentheses; $+<=10 \%, *<=5 \%, * *<=1 \%$.

${ }^{4}$ Implicit value based on partial derivative of hedonic for continuous variables

5 Implicit value based on discrete change from 0 to 1 for dummy variables

62703 households; bootstrapped 250 times.

${ }^{7}$ Mean of Chi-squared tests of nonlinearity in parameters $(60.02 \mathrm{df})=253.86, p<.001$. 
Table 2. Mean value of simulated interventions

\begin{tabular}{|c|c|c|c|c|}
\hline $\begin{array}{l}\text { Dependent variable: log of estimated } \\
\text { monthly rental value (Rupees) }\end{array}$ & $\begin{array}{r}\text { Mean value } \\
\text { of attribute } \\
\text { (Rupees) }\end{array}$ & $\begin{array}{r}\text { Mean value } \\
\text { of change } \\
\text { (Rupees) }\end{array}$ & $\begin{array}{r}\text { Percent } \\
\text { change }\end{array}$ & $\begin{array}{r}\text { Unit } \\
\text { change }\end{array}$ \\
\hline \multicolumn{5}{|l|}{ Own dwelling characteristics } \\
\hline Mains water $^{1}$ & 161.52 & 161.52 & 100.00 & 1.00 \\
\hline Sewer ${ }^{1}$ & 76.06 & 76.06 & 100.00 & 1.00 \\
\hline Distance to bus stop ${ }^{2}$ & -61.26 & 23.48 & -39.70 & -2.81 \\
\hline \multicolumn{5}{|l|}{ Neighborhood characteristics ${ }^{2}$} \\
\hline Number of parks within $1 \mathrm{~km}$ & -4.52 & -4.19 & 101.48 & 12.73 \\
\hline Number of schools within $1 \mathrm{~km}$ & 122.22 & 68.19 & 54.44 & 5.02 \\
\hline Property tax rate (\%) & 29.06 & 11.17 & 39.38 & 0.27 \\
\hline \multicolumn{5}{|l|}{ Neighbor attitudes ${ }^{2}$} \\
\hline Share who feel neighborhood is safe & 260.49 & 29.32 & 11.18 & 0.09 \\
\hline Share who feel air is polluted & -227.67 & 16.21 & -7.12 & -0.06 \\
\hline
\end{tabular}

\footnotetext{
${ }^{1}$ Dummy variable, change from 0 to 1 .

${ }^{2}$ Continuous variables, change of $1 / 2$ of one standard deviation around the mean.
} 
Table 3.1. Willingness to pay for dwelling unit attributes

\begin{tabular}{|c|c|c|c|c|c|c|}
\hline & \multicolumn{6}{|c|}{ Dependent variable: value of improvement in } \\
\hline & \multicolumn{2}{|c|}{ Mains water ${ }^{1}$} & \multicolumn{2}{|c|}{ Sewer $^{1}$} & \multicolumn{2}{|c|}{ Distance to bus ${ }^{2}$} \\
\hline & Value & $\mathrm{SE}$ & Value & SE & Value & SE \\
\hline Scheduled caste & -9.86 & $(5.13)+$ & 0.31 & $(1.99)$ & -6.89 & $(4.21)$ \\
\hline HH head age & 0.61 & $(0.19) * *$ & 0.06 & $(0.07)$ & 0.79 & $(0.16) * *$ \\
\hline HH head higher educ & 4.48 & $(7.30)$ & 10.15 & $(2.33) * *$ & 26.84 & $(5.83) * *$ \\
\hline HH size & -0.09 & $(1.20)$ & -0.30 & $(0.47)$ & 1.14 & $(0.98)$ \\
\hline HH head born in Pune & 13.96 & $(5.18) * *$ & 4.35 & $(2.08) *$ & 0.03 & $(4.31)$ \\
\hline Years in dwelling & 0.44 & $(0.10) * *$ & 0.18 & $(0.04) * *$ & -0.14 & $(0.08)+$ \\
\hline Income from durables $^{3}$ & 0.43 & $(0.20) *$ & 0.16 & $(0.08)+$ & 1.74 & $(0.15) * *$ \\
\hline Household owns dwelling̨ & 80.70 & $(3.67) * *$ & -4.84 & $(2.00) *$ & 13.58 & $(4.37) * *$ \\
\hline
\end{tabular}

${ }^{1}$ Change from 0 to 1 .

${ }^{2}$ Change of $1 / 2$ of one standard deviation around the mean.

${ }^{3}$ x 1000 Rupees.

Table 3.2. Willingness to pay for neighborhood attributes

\begin{tabular}{|c|c|c|c|c|c|c|}
\hline & \multicolumn{6}{|c|}{ Dependent variable: value of improvement ${ }^{1}$ in } \\
\hline & \multicolumn{2}{|c|}{$\begin{array}{l}\text { Number of parks } \\
\text { within } 1 \text { km }\end{array}$} & \multicolumn{2}{|c|}{$\begin{array}{l}\text { Number of schools } \\
\text { w/in } 1 \text { km }\end{array}$} & \multicolumn{2}{|c|}{$\begin{array}{c}\text { Mean neighborhood } \\
\text { property tax rate }(\%)\end{array}$} \\
\hline & Value & $\mathrm{SE}$ & Value & $\mathrm{SE}$ & Value & $\mathrm{SE}$ \\
\hline Scheduled caste & 1.22 & $(2.61)$ & -35.13 & $(15.68) *$ & -5.32 & $(3.36)$ \\
\hline HH head age & -0.03 & $(0.10)$ & 2.84 & $(0.58) * *$ & 0.27 & $(0.12) *$ \\
\hline HH head higher educ & 0.28 & $(3.62)$ & 85.32 & $(21.73) * *$ & 10.31 & $(4.67) *$ \\
\hline HH size & -0.14 & $(0.61)$ & -3.41 & $(3.64)$ & 0.44 & $(0.78)$ \\
\hline HH head born in Pune & 1.14 & $(2.67)$ & 15.61 & $(16.04)$ & -0.42 & $(3.44)$ \\
\hline Years in dwelling & 0.01 & $(0.05)$ & 1.59 & $(0.29) * *$ & -0.13 & $(0.06) *$ \\
\hline Income from durables $^{2}$ & -0.09 & $(0.09)$ & 4.87 & $(0.56) * *$ & 0.81 & $(0.12) * *$ \\
\hline Household owns dwelling̨ & -1.42 & $(2.71)$ & -15.70 & $(16.26)$ & 12.87 & $(3.49) * *$ \\
\hline
\end{tabular}

${ }^{1}$ Change of $1 / 2$ of one standard deviation around the mean.

${ }^{2}$ x 1000 Rupees.

Table 3.3. Willingness to pay for neighbor attitudes

\begin{tabular}{|c|c|c|c|c|}
\hline & \multicolumn{4}{|c|}{ Dependent variable: value of improvement ${ }^{1}$ in } \\
\hline & \multicolumn{4}{|c|}{$\begin{array}{c}\text { Share who feel area is } \begin{array}{c}\text { Share who feel air is } \\
\text { safe }\end{array} \text { polluted }\end{array}$} \\
\hline & Value & SE & Value & SE \\
\hline Scheduled caste & -49.92 & $(17.22) * *$ & -47.25 & $(18.52) *$ \\
\hline HH head age & 4.22 & $(0.64) * *$ & 3.69 & $(0.68) * *$ \\
\hline HH head higher educ & 148.86 & $(23.82) * *$ & 131.03 & $(25.67) * *$ \\
\hline HH size & -2.66 & $(4.00)$ & -3.03 & $(4.31)$ \\
\hline HH head born in Pune & 12.58 & $(17.63)$ & 6.31 & $(18.96)$ \\
\hline Years in dwelling & 0.25 & $(0.32)$ & -0.06 & $(0.35)$ \\
\hline Income from durables $^{2}$ & 9.69 & $(0.61) * *$ & 8.00 & $(0.66) * *$ \\
\hline Household owns dwelling̨ & 48.42 & $(17.85) * *$ & 48.04 & $(19.20) *$ \\
\hline
\end{tabular}


Table 4. Value of service improvement expressed as percent of estimated monthly rent

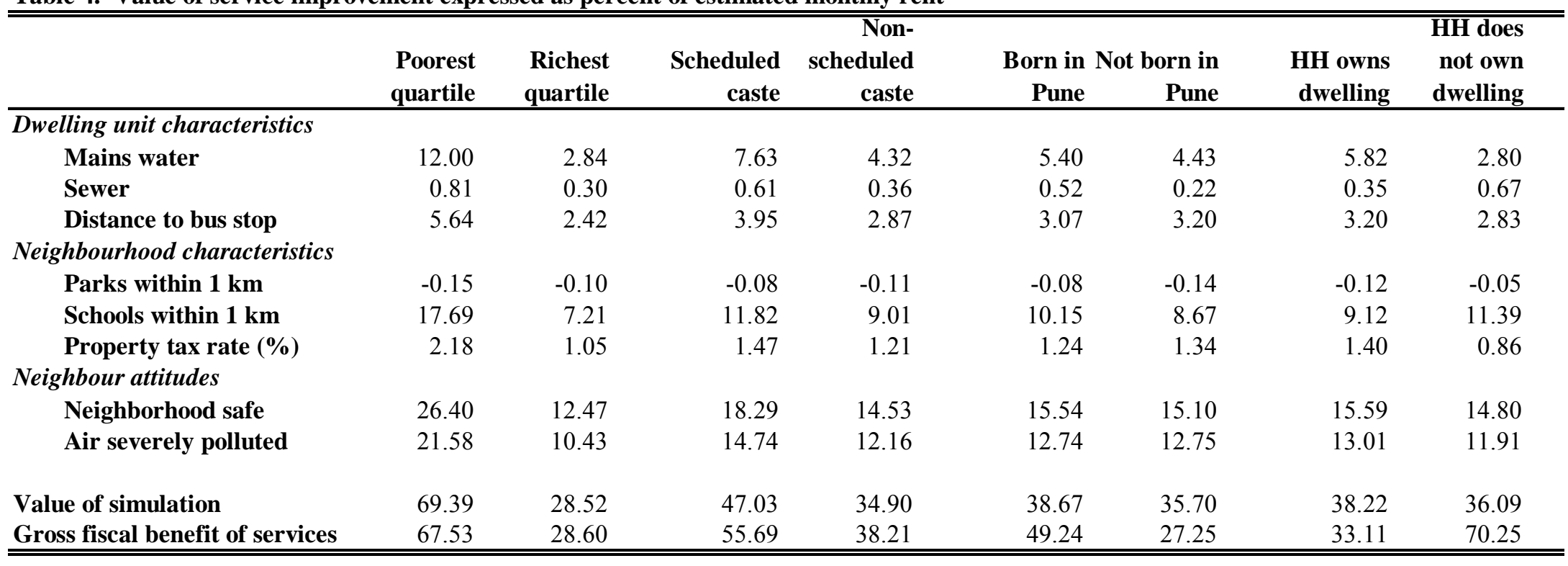


Figure 1A. Smoothed partial plot: rent as a function of the distance to the nearest bus stop.

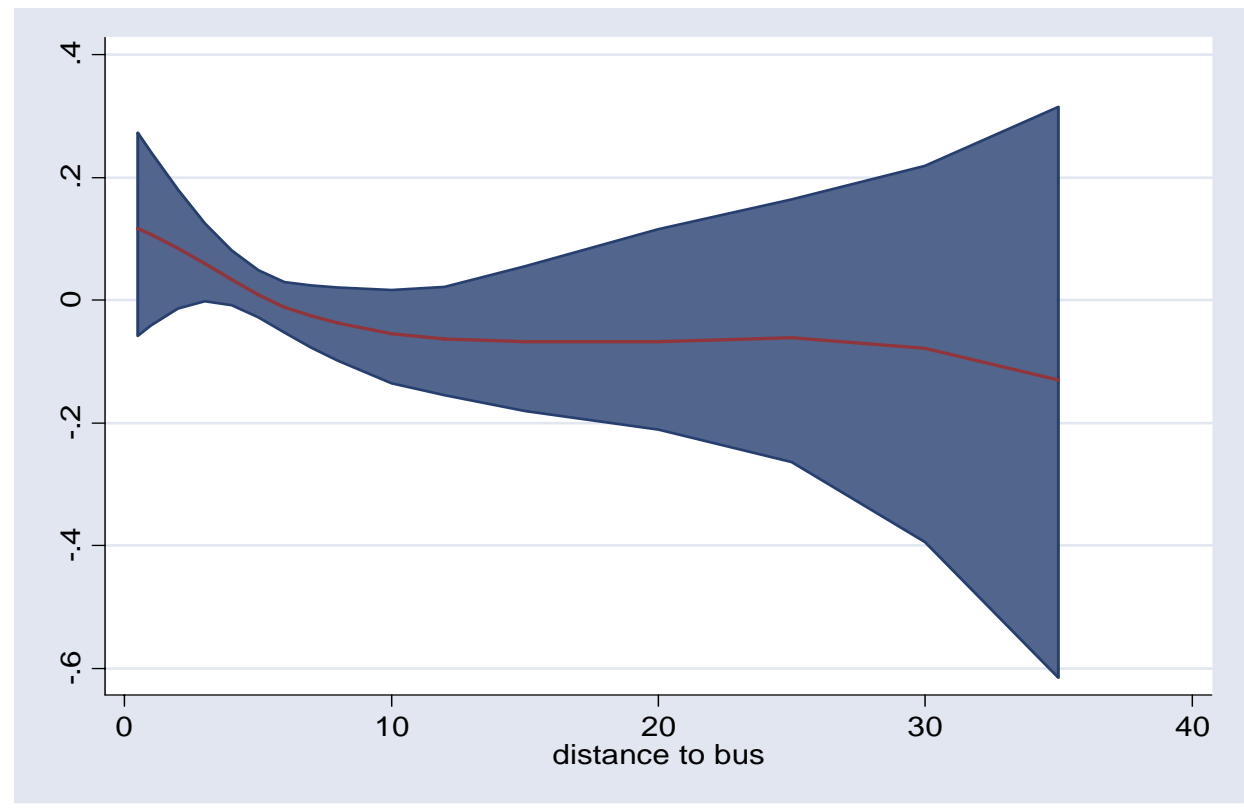

Figure 1B. Smoothed partial plot: rent as a function of the number of schools within one kilometer.

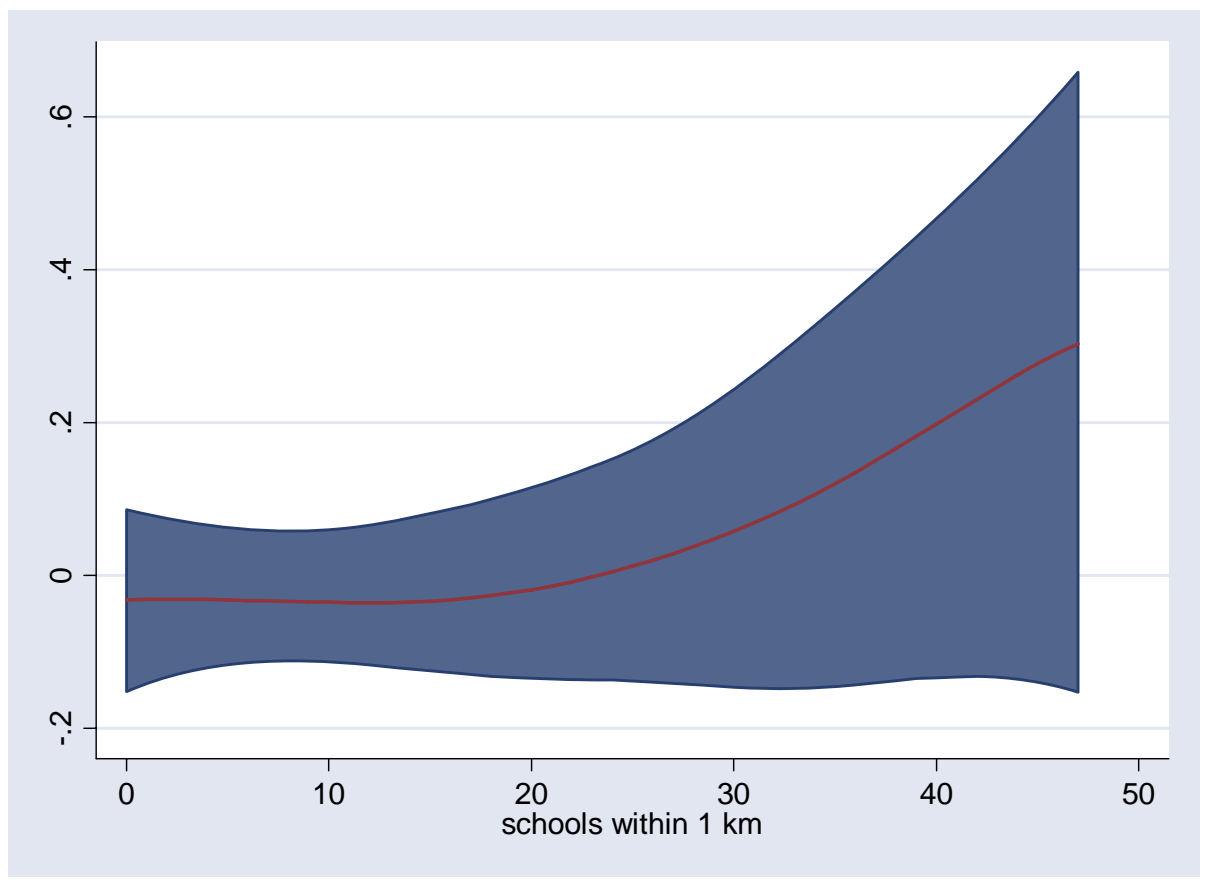


Appendix Table 1A. Descriptive statistics for households

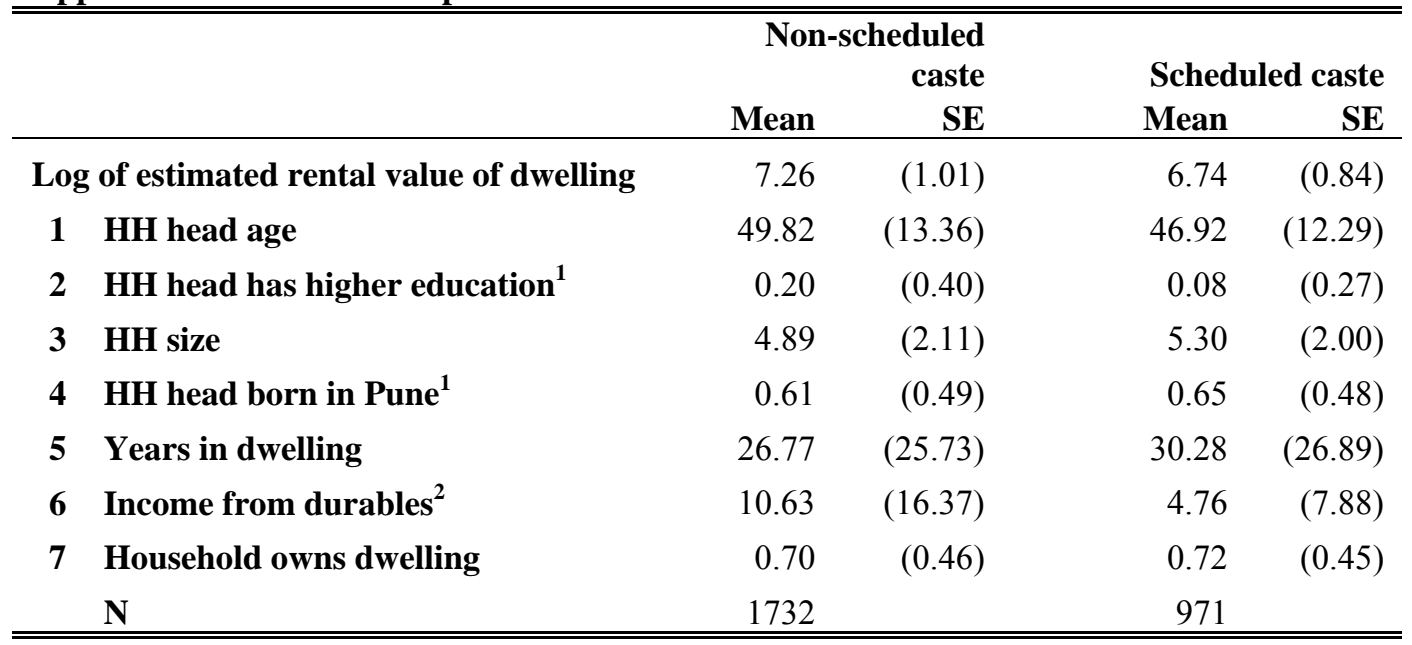

1 Dummy variables.

2 Income from durable goods * 1000 Rupees. 
Appendix Table 1B. Descriptive statistics for housing

\begin{tabular}{|c|c|c|c|c|c|c|}
\hline \multirow{2}{*}{\multicolumn{2}{|c|}{ Log of estimated rental value of dwelling }} & \multirow{2}{*}{$\begin{array}{r}\text { Mean } \\
7.07\end{array}$} & \multirow{2}{*}{$\frac{\text { SE }}{(0.98)}$} & \multicolumn{2}{|c|}{$\begin{array}{c}\text { Implicit value of } \\
\text { attribute (Rupees) }\end{array}$} & \multirow[t]{2}{*}{$\begin{array}{c}\text { Value of } \\
\text { simulated change } \\
\text { (Rupees) }^{4}\end{array}$} \\
\hline & & & & & & \\
\hline \multicolumn{7}{|c|}{ Own dwelling characteristics } \\
\hline 1 & Mains water ${ }^{1}$ & 0.56 & $(0.50)$ & 161.52 & $(53.84)$ & 161.52 \\
\hline 2 & Sewer $^{1}$ & 0.78 & $(0.41)$ & 76.06 & $(64.81)$ & 76.06 \\
\hline 3 & House $^{1}$ & 0.10 & $(0.30)$ & 10.91 & $(87.85)$ & 10.91 \\
\hline 4 & Attached $^{1}$ & 0.71 & $(0.45)$ & -191.30 & $(55.05)$ & -191.30 \\
\hline 5 & Living space $^{2}$ & 417.41 & (441.12) & 1208.71 & (208.77) & 706.09 \\
\hline 6 & Good roof ${ }^{1}$ & 0.39 & $(0.49)$ & 204.94 & $(71.66)$ & 204.94 \\
\hline 7 & Good exterior $^{1}$ & 0.40 & $(0.49)$ & 416.46 & $(72.70)$ & 416.46 \\
\hline 8 & Distance to bus ${ }^{2}$ & 7.33 & $(5.65)$ & -61.26 & $(31.89)$ & 23.48 \\
\hline 9 & Slum $^{1}$ & 0.33 & $(0.47)$ & -317.05 & $(41.16)$ & -317.05 \\
\hline \multicolumn{7}{|c|}{ Neighborhood characteristics ${ }^{2}$} \\
\hline 10 & Share houses & 0.09 & $(0.10)$ & 18.17 & $(47.99)$ & 10.02 \\
\hline 11 & Share attached & 0.72 & $(0.21)$ & -107.20 & $(185.61)$ & -15.71 \\
\hline 12 & Mean living space & 309.18 & $(103.89)$ & -90.95 & $(249.83)$ & -15.93 \\
\hline 13 & Share with good roof & 0.38 & $(0.22)$ & -78.59 & $(143.90)$ & -22.99 \\
\hline 14 & Share with good exterior & 0.39 & $(0.19)$ & 294.13 & $(161.42)$ & 70.70 \\
\hline 15 & Share slum & 0.34 & $(0.30)$ & 116.11 & $(67.93)$ & 51.80 \\
\hline 16 & Parks within 1 km & 13.73 & $(25.73)$ & -4.52 & $(18.38)$ & -4.19 \\
\hline 17 & Schools within 1 km & 9.00 & $(10.01)$ & 122.22 & $(81.00)$ & 68.19 \\
\hline 18 & Mean property tax rate (percent) & 0.70 & $(0.52)$ & 29.06 & $(43.67)$ & 11.17 \\
\hline 19 & Residential density (1000 units/ha) & 3.58 & $(3.70)$ & 25.64 & $(29.56)$ & 13.32 \\
\hline \multicolumn{7}{|c|}{ Neighbor characteristics ${ }^{2}$} \\
\hline 20 & Share scheduled caste & 0.37 & $(0.17)$ & -142.69 & $(83.06)$ & -32.09 \\
\hline 21 & Mean years in dwelling & 20.32 & $(10.87)$ & 188.05 & $(106.63)$ & 51.58 \\
\hline 22 & Share hh heads with higher educ & 0.15 & $(0.16)$ & 136.30 & $(83.61)$ & 80.22 \\
\hline 23 & Mean durables income ${ }^{3}$ & 4.29 & $(2.47)$ & 88.85 & $(161.40)$ & 28.89 \\
\hline 24 & Mean log deviation durables & 0.63 & $(0.22)$ & 43.46 & $(101.79)$ & 7.52 \\
\hline 25 & Share owners & 0.71 & $(0.19)$ & -310.73 & $(188.85)$ & -42.23 \\
\hline 26 & Share who feel neighborhood is safe & 0.77 & $(0.18)$ & 260.49 & (193.10) & 29.32 \\
\hline \multirow[t]{2}{*}{27} & Share who feel air pollution is severe & 0.86 & $(0.13)$ & -227.67 & $(339.58)$ & 16.21 \\
\hline & $\mathbf{N}$ & 2703 & & & & \\
\hline 1 & Dummy variables. & & & & & \\
\hline 2 & Continuous variables. & & & & & \\
\hline 3 & $\begin{array}{l}\text { Income from durable goods * } 1000 \text { Rupees } \\
\text { For dummy variables, the value of a chang } \\
\text { change around the mean. }\end{array}$ & $0+1$. & . & th & & \\
\hline
\end{tabular}


Appendix Table 2. GAM results, first-stage hedonic estimates ${ }^{5,6}$

\begin{tabular}{|c|c|c|}
\hline \multirow{2}{*}{$\begin{array}{l}\text { Dependent variable: log of estimated } \\
\text { monthly rental value } \\
\text { Own dwelling characteristics }\end{array}$} & \multicolumn{2}{|c|}{ First stage hedonic estimates ${ }^{4}$} \\
\hline & & \\
\hline 1 Mains water ${ }^{1}$ & 0.129 & $(0.04) * *$ \\
\hline 2 Sewer $^{1}$ & 0.062 & $(0.05)$ \\
\hline 3 House $^{1}$ & 0.009 & $(0.08)$ \\
\hline 4 Attached $^{1}$ & -0.177 & $(0.06) * *$ \\
\hline 5 Living space ${ }^{2}$ & 0.001 & $(0.00) * *$ \\
\hline 6 Good roof ${ }^{1}$ & 0.160 & $(0.05) * *$ \\
\hline 7 Good exterior ${ }^{1}$ & 0.303 & $(0.04) * *$ \\
\hline 8 Distance to bus ${ }^{2}$ & -0.006 & $(0.00)+$ \\
\hline 9 Slum $^{1}$ & -0.314 & $(0.05) * *$ \\
\hline \multicolumn{3}{|l|}{ Neighborhood characteristics ${ }^{2}$} \\
\hline 10 Share houses & 0.099 & $(0.26)$ \\
\hline 11 Share attached & -0.102 & $(0.18)$ \\
\hline 12 Mean living space & 0.000 & $(0.00)$ \\
\hline 13 Share with good roof & -0.104 & $(0.19)$ \\
\hline 14 Share with good exterior & 0.388 & $(0.18) *$ \\
\hline 15 Share slum & 0.291 & $(0.13) *$ \\
\hline 16 Parks within 1 km & 0.000 & $(0.00)$ \\
\hline 17 Schools within 1 km & 0.005 & $(0.00) *$ \\
\hline 18 Mean property tax rate (percent) & 0.028 & $(0.04)$ \\
\hline 19 Residential density (1000 units/ha) & 0.004 & $(0.01)$ \\
\hline \multicolumn{3}{|l|}{ Neighbor characteristics ${ }^{2}$} \\
\hline 20 Share scheduled caste & -0.271 & $(0.15)+$ \\
\hline 21 Mean years in dwelling & 0.006 & $(0.00) *$ \\
\hline 22 Share hh heads with higher educ & 0.367 & $(0.18) *$ \\
\hline 23 Mean durables income ${ }^{3}$ & 0.010 & $(0.02)$ \\
\hline 24 Mean log deviation durables & 0.040 & $(0.09)$ \\
\hline 25 Share owners & -0.279 & $(0.14)+$ \\
\hline 26 Share who feel neighborhood is safe & 0.198 & $(0.13)$ \\
\hline 27 Share who feel air pollution is severe & -0.161 & $(0.22)$ \\
\hline
\end{tabular}

Notes:

${ }^{1}$ Dummy variables.

${ }^{2}$ Continuous variables.

${ }^{3}$ Income from durable goods * 1000 Rupees.

${ }^{4}$ Standard error in parentheses; $+<=10 \%,{ }^{*}<=5 \%,{ }^{*}<=1 \%$.

52703 households; bootstrapped 250 times.

${ }^{6}$ Mean of Chi-squared tests of nonlinearity in parameters $(60.02 \mathrm{df})=253.86, \mathrm{p}<.001$. 


\begin{tabular}{|c|c|c|c|c|c|c|c|c|c|}
\hline \multirow[b]{2}{*}{$\begin{array}{l}\text { Demand for dwelling unit } \\
\text { characteristic }\end{array}$} & \multicolumn{9}{|c|}{ Explanatory variables } \\
\hline & $\begin{array}{c}\text { Scheduled } \\
\text { caste }\end{array}$ & HH head age & $\begin{array}{c}\text { HH head } \\
\text { higher educ }\end{array}$ & HH size & $\begin{array}{c}\text { HH head born } \\
\text { in Pune }\end{array}$ & $\begin{array}{l}\text { Years in } \\
\text { dwelling }\end{array}$ & $\begin{array}{c}\text { Income from } \\
\text { durables }\end{array}$ & $\begin{array}{c}\text { HH owns } \\
\text { dwelling }\end{array}$ & Intercept \\
\hline Residual & $\begin{array}{c}-0.048 \\
(17.22)\end{array}$ & $\begin{array}{l}0.000 \\
(0.64)\end{array}$ & $\begin{array}{c}0.090 \\
(23.82)+\end{array}$ & $\begin{array}{l}-0.002 \\
(4.00)\end{array}$ & $\begin{array}{r}-0.038 \\
(17.63)\end{array}$ & $\begin{array}{l}0.001 \\
(0.32)\end{array}$ & $\begin{array}{l}0.004 \\
(0.61) * *\end{array}$ & $\begin{array}{r}0.027 \\
(17.85)\end{array}$ & $\begin{array}{c}-0.039 \\
(38.52)\end{array}$ \\
\hline Mains water ${ }^{1}$ & $\begin{array}{l}-9.865 \\
(5.13)+\end{array}$ & $\begin{array}{l}0.608 \\
(0.19) * *\end{array}$ & $\begin{array}{r}4.477 \\
(7.30)\end{array}$ & $\begin{array}{l}-0.088 \\
(1.20)\end{array}$ & $\begin{array}{l}13.959 \\
(5.18) * *\end{array}$ & $\begin{array}{l}0.439 \\
(0.10) * *\end{array}$ & $\begin{array}{l}0.428 \\
(0.20) *\end{array}$ & $\begin{array}{l}80.701 \\
(3.67) * *\end{array}$ & $\begin{array}{c}-304.759 \\
(31.27) * *\end{array}$ \\
\hline Sewer $^{1}$ & $\begin{array}{l}0.307 \\
(1.99)\end{array}$ & $\begin{array}{l}0.060 \\
(0.07)\end{array}$ & $\begin{array}{l}10.152 \\
(2.33) * *\end{array}$ & $\begin{array}{l}-0.304 \\
(0.47)\end{array}$ & $\begin{array}{l}4.354 \\
(2.08) *\end{array}$ & $\begin{array}{l}0.185 \\
(0.04) * *\end{array}$ & $\begin{array}{l}0.160 \\
(0.08)+\end{array}$ & $\begin{array}{l}-4.838 \\
(2.00) *\end{array}$ & $\begin{array}{c}59.662 \\
(29.97)^{*}\end{array}$ \\
\hline House $^{1}$ & $\begin{array}{l}-0.296 \\
(0.17)+\end{array}$ & $\begin{array}{l}0.020 \\
(0.01)^{* *}\end{array}$ & $\begin{array}{l}0.170 \\
(0.24)\end{array}$ & $\begin{array}{l}-0.025 \\
(0.04)\end{array}$ & $\begin{array}{l}0.156 \\
(0.17)\end{array}$ & $\begin{array}{c}-0.003 \\
(0.00)\end{array}$ & $\begin{array}{l}0.020 \\
(0.01)^{* *}\end{array}$ & $\begin{array}{l}0.483 \\
(0.17)^{* *}\end{array}$ & $\begin{array}{c}-356.593 \\
(40.05)\end{array}$ \\
\hline Attached & $\begin{array}{l}-16.597 \\
\quad(3.78) * *\end{array}$ & $\begin{array}{l}0.844 \\
(0.15) * *\end{array}$ & $\begin{array}{l}41.403 \\
(7.51)^{* *}\end{array}$ & $\begin{array}{l}-3.264 \\
(0.98) * *\end{array}$ & $\begin{array}{r}-1.286 \\
(4.15)\end{array}$ & $\begin{array}{l}-0.738 \\
(0.09) * *\end{array}$ & $\begin{array}{l}1.186 \\
(0.18) * *\end{array}$ & $\begin{array}{l}4.898 \\
(4.05)\end{array}$ & $\begin{array}{l}186.507 \\
(31.13) \text { ** }\end{array}$ \\
\hline Living space & $\begin{array}{l}-257.771 \\
(274.14)\end{array}$ & $\begin{array}{l}41.389 \\
(10.14) * *\end{array}$ & $\begin{array}{l}684.236 \\
(379.58)+\end{array}$ & $\begin{array}{l}87.655 \\
(63.62)\end{array}$ & $\begin{array}{r}13.161 \\
(280.46)\end{array}$ & $\begin{array}{l}0.430 \\
(5.16)\end{array}$ & $\begin{array}{l}120.092 \\
(9.75) * *\end{array}$ & $\begin{array}{l}528.680 \\
(284.10)+\end{array}$ & $\begin{array}{c}-2685.806 \\
(613.09) * *\end{array}$ \\
\hline Good roof ${ }^{1}$ & $\begin{array}{r}-24.503 \\
(5.00) * *\end{array}$ & $\begin{array}{l}0.861 \\
(0.20) * *\end{array}$ & $\begin{array}{l}58.171 \\
(9.08) * *\end{array}$ & $\begin{array}{l}-3.443 \\
(1.27) * *\end{array}$ & $\begin{array}{l}-3.302 \\
(5.59)\end{array}$ & $\begin{array}{l}-0.840 \\
(0.11) * *\end{array}$ & $\begin{array}{l}1.751 \\
(0.26)\end{array}$ ** & $\begin{array}{l}18.893 \\
(5.16) * *\end{array}$ & $\begin{array}{c}-140.442 \\
(29.44)\end{array} * *$ \\
\hline Good exterior ${ }^{1}$ & $\begin{array}{r}-1.350 \\
(8.09)\end{array}$ & $\begin{array}{l}0.698 \\
(0.30) *\end{array}$ & $\begin{array}{l}77.870 \\
(15.44) * *\end{array}$ & $\begin{array}{l}-3.425 \\
(1.92)+\end{array}$ & $\begin{array}{r}-1.956 \\
(8.39)\end{array}$ & $\begin{array}{l}-0.671 \\
(0.16)^{* *}\end{array}$ & $\begin{array}{l}1.939 \\
(0.35)^{* *}\end{array}$ & $\begin{array}{l}32.646 \\
(7.49) * *\end{array}$ & $\begin{array}{c}-171.689 \\
(28.21) * *\end{array}$ \\
\hline Distance to bus & $\begin{array}{l}-6.889 \\
(4.21)\end{array}$ & $\begin{array}{l}0.794 \\
(0.16) * *\end{array}$ & $\begin{array}{l}26.843 \\
(5.83) * *\end{array}$ & $\begin{array}{l}1.143 \\
(0.98)\end{array}$ & $\begin{array}{l}0.030 \\
(4.31)\end{array}$ & $\begin{array}{l}-0.140 \\
(0.08)+\end{array}$ & $\begin{array}{l}1.737 \\
(0.15) * *\end{array}$ & $\begin{array}{l}13.582 \\
(4.37) * *\end{array}$ & $\begin{array}{l}-5.492 \\
(9.43)\end{array}$ \\
\hline Slum ${ }^{1}$ & $\begin{array}{l}62.064 \\
(10.15) * *\end{array}$ & $\begin{array}{l}-2.297 \\
(0.41) * *\end{array}$ & $\begin{array}{l}-113.813 \\
(13.01)^{* *}\end{array}$ & $\begin{array}{l}7.876 \\
(2.50) * *\end{array}$ & $\begin{array}{l}-36.978 \\
(10.93) * *\end{array}$ & $\begin{array}{l}-0.756 \\
(0.22) * *\end{array}$ & $\begin{array}{l}-4.184 \\
(0.67)^{* *}\end{array}$ & $\begin{array}{r}121.873 \\
(9.35)^{* *}\end{array}$ & $\begin{array}{r}12.325 \\
(30.77)\end{array}$ \\
\hline Share houses & $\begin{array}{l}-4.340 \\
(5.00)\end{array}$ & $\begin{array}{l}0.374 \\
(0.18) *\end{array}$ & $\begin{array}{l}11.633 \\
(6.92)+\end{array}$ & $\begin{array}{l}-0.054 \\
(1.16)\end{array}$ & $\begin{array}{l}1.267 \\
(5.12)\end{array}$ & $\begin{array}{r}-0.134 \\
(0.09)\end{array}$ & $\begin{array}{l}0.949 \\
(0.18) * *\end{array}$ & $\begin{array}{l}4.466 \\
(5.18)\end{array}$ & $\begin{array}{r}-8.572 \\
(11.19)\end{array}$ \\
\hline Share attached & $\begin{array}{l}19.613 \\
(9.34) *\end{array}$ & $\begin{array}{l}-1.103 \\
(0.34) * *\end{array}$ & $\begin{array}{l}-30.978 \\
(12.90) *\end{array}$ & $\begin{array}{r}-1.577 \\
(2.17)\end{array}$ & $\begin{array}{r}-7.916 \\
(9.56)\end{array}$ & $\begin{array}{r}-0.177 \\
(0.18)\end{array}$ & $\begin{array}{l}-2.535 \\
(0.33) * *\end{array}$ & $\begin{array}{l}-25.588 \\
(9.68) * *\end{array}$ & $\begin{array}{r}2.489 \\
(20.88)\end{array}$ \\
\hline Mean living space & $\begin{array}{l}20.588 \\
(15.90)\end{array}$ & $\begin{array}{l}-1.858 \\
(0.59) * *\end{array}$ & $\begin{array}{l}-74.268 \\
(22.04) * *\end{array}$ & $\begin{array}{l}2.846 \\
(3.69)\end{array}$ & $\begin{array}{r}-1.442 \\
(16.27)\end{array}$ & $\begin{array}{l}0.200 \\
(0.30)\end{array}$ & $\begin{array}{l}-3.665 \\
(0.57)^{* *}\end{array}$ & $\begin{array}{r}-17.976 \\
(16.48)\end{array}$ & $\begin{array}{l}28.385 \\
(35.58)\end{array}$ \\
\hline Share with good roof & $\begin{array}{c}18.829 \\
(10.94)+\end{array}$ & $\begin{array}{l}-1.829 \\
(0.40) * *\end{array}$ & $\begin{array}{l}-70.677 \\
(15.12) * *\end{array}$ & $\begin{array}{l}3.355 \\
(2.54)\end{array}$ & $\begin{array}{r}3.221 \\
(11.19)\end{array}$ & $\begin{array}{l}0.277 \\
(0.20)\end{array}$ & $\begin{array}{l}-3.821 \\
(0.39) * *\end{array}$ & $\begin{array}{l}-14.206 \\
(11.35)\end{array}$ & $\begin{array}{l}30.734 \\
(24.46)\end{array}$ \\
\hline Share with good exterior & $\begin{array}{l}-53.861 \\
(24.45) *\end{array}$ & $\begin{array}{l}6.041 \\
(0.90) * *\end{array}$ & $\begin{array}{l}234.942 \\
(33.79) * *\end{array}$ & $\begin{array}{r}-10.976 \\
(5.67)+\end{array}$ & $\begin{array}{l}-12.421 \\
(25.00)\end{array}$ & $\begin{array}{l}-0.831 \\
(0.46)+\end{array}$ & $\begin{array}{l}13.878 \\
(0.87) * *\end{array}$ & $\begin{array}{l}60.478 \\
(25.33) *\end{array}$ & $\begin{array}{l}-92.262 \\
(54.68)+\end{array}$ \\
\hline Share slum & $\begin{array}{l}1.584 \\
(8.84)\end{array}$ & $\begin{array}{l}0.495 \\
(0.33)\end{array}$ & $\begin{array}{r}19.788 \\
(12.20)\end{array}$ & $\begin{array}{l}4.596 \\
(2.05) *\end{array}$ & $\begin{array}{r}-12.119 \\
(9.04)\end{array}$ & $\begin{array}{l}-0.637 \\
(0.17) * *\end{array}$ & $\begin{array}{l}2.750 \\
(0.31)^{* *}\end{array}$ & $\begin{array}{l}58.657 \\
(9.16) * *\end{array}$ & $\begin{array}{l}26.077 \\
(19.79)\end{array}$ \\
\hline Parks within 1 km & $\begin{array}{l}1.215 \\
(2.61)\end{array}$ & $\begin{array}{l}-0.025 \\
(0.10)\end{array}$ & $\begin{array}{l}0.283 \\
(3.62)\end{array}$ & $\begin{array}{l}-0.140 \\
(0.61)\end{array}$ & $\begin{array}{l}1.137 \\
(2.67)\end{array}$ & $\begin{array}{l}0.010 \\
(0.05)\end{array}$ & $\begin{array}{l}-0.092 \\
(0.09)\end{array}$ & $\begin{array}{l}-1.424 \\
(2.71)\end{array}$ & $\begin{array}{r}-2.365 \\
(5.83)\end{array}$ \\
\hline Schools within $1 \mathrm{~km}$ & $\begin{array}{l}-35.126 \\
(17.22) *\end{array}$ & $\begin{array}{l}2.837 \\
(0.64) * *\end{array}$ & $\begin{array}{l}85.319 \\
(23.82) * *\end{array}$ & $\begin{array}{l}-3.414 \\
(4.00)\end{array}$ & $\begin{array}{r}15.613 \\
(17.63)\end{array}$ & $\begin{array}{l}1.588 \\
(0.32) * *\end{array}$ & $\begin{array}{l}4.875 \\
(0.61)^{* *}\end{array}$ & $\begin{array}{r}-15.701 \\
(17.85)\end{array}$ & $\begin{array}{l}-84.956 \\
(38.52) *\end{array}$ \\
\hline Mean property tax rate (\%) & $\begin{array}{r}-5.323 \\
(3.36)\end{array}$ & $\begin{array}{l}0.267 \\
(0.12) *\end{array}$ & $\begin{array}{c}10.311 \\
(4.67) *\end{array}$ & $\begin{array}{l}0.444 \\
(0.78)\end{array}$ & $\begin{array}{r}-0.418 \\
(3.44)\end{array}$ & $\begin{array}{l}-0.126 \\
(0.06)\end{array}$ & $\begin{array}{l}0.811 \\
(0.12) * *\end{array}$ & $\begin{array}{l}12.873 \\
(3.49) * *\end{array}$ & $\begin{array}{l}1.961 \\
(7.52)\end{array}$ \\
\hline Residential density (1000 units/ha) & $\begin{array}{l}-6.621 \\
(3.04) *\end{array}$ & $\begin{array}{l}0.356 \\
(0.11) * *\end{array}$ & $\begin{array}{l}15.285 \\
(4.21) * *\end{array}$ & $\begin{array}{l}0.076 \\
(0.71)\end{array}$ & $\begin{array}{l}5.109 \\
(3.11)+\end{array}$ & $\begin{array}{l}0.086 \\
(0.06)\end{array}$ & $\begin{array}{l}0.595 \\
(0.11) * *\end{array}$ & $\begin{array}{l}7.481 \\
(3.15) *\end{array}$ & $\begin{array}{r}-8.306 \\
(6.81)\end{array}$ \\
\hline Share scheduled caste & $\begin{array}{r}6.476 \\
(8.76)\end{array}$ & $\begin{array}{l}-1.192 \\
(0.32) * *\end{array}$ & $\begin{array}{l}-30.262 \\
(12.12) *\end{array}$ & $\begin{array}{l}-3.911 \\
(2.04)+\end{array}$ & $\begin{array}{l}-4.213 \\
(8.97)\end{array}$ & $\begin{array}{l}0.036 \\
(0.16)\end{array}$ & $\begin{array}{l}-4.049 \\
(0.31)^{* *}\end{array}$ & $\begin{array}{r}-28.366 \\
(9.09) * *\end{array}$ & $\begin{array}{l}-5.949 \\
(19.62)\end{array}$ \\
\hline Mean years in dwelling & 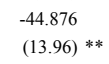 & $\begin{array}{l}2.779 \\
(0.52) * *\end{array}$ & $\begin{array}{l}90.962 \\
(19.32) * *\end{array}$ & $\begin{array}{l}0.176 \\
(3.24)\end{array}$ & $\begin{array}{r}21.666 \\
(14.27)\end{array}$ & $\begin{array}{l}1.695 \\
(0.26) * *\end{array}$ & $\begin{array}{l}5.755 \\
(0.50) * *\end{array}$ & $\begin{array}{r}7.271 \\
(14.46)\end{array}$ & $\begin{array}{l}-62.820 \\
(31.18) *\end{array}$ \\
\hline Share hh heads with higher educ & $\begin{array}{l}-44.688 \\
(17.90) *\end{array}$ & $\begin{array}{l}3.960 \\
(0.66) * *\end{array}$ & $\begin{array}{l}183.619 \\
(24.78)\end{array} * *$ & $\begin{array}{r}-13.151 \\
(4.15) * *\end{array}$ & $\begin{array}{r}-3.180 \\
(18.30)\end{array}$ & $\begin{array}{r}-0.427 \\
(0.34)\end{array}$ & $\begin{array}{l}7.871 \\
(0.64) * *\end{array}$ & $\begin{array}{l}28.028 \\
(18.57)\end{array}$ & $\begin{array}{l}-76.030 \\
(40.05)+\end{array}$ \\
\hline Mean durables income & $\begin{array}{l}-24.238 \\
(16.20)\end{array}$ & $\begin{array}{l}2.172 \\
(0.60) * *\end{array}$ & $\begin{array}{l}101.002 \\
(22.49) * *\end{array}$ & $\begin{array}{r}-4.358 \\
(3.77)\end{array}$ & $\begin{array}{r}-1.379 \\
(16.58)\end{array}$ & $\begin{array}{l}-0.026 \\
(0.31)\end{array}$ & $\begin{array}{l}4.311 \\
(0.58) * *\end{array}$ & $\begin{array}{r}14.184 \\
(16.79)\end{array}$ & $\begin{array}{l}-46.613 \\
(36.23)\end{array}$ \\
\hline Mean log deviation durables & $\begin{array}{r}-7.442 \\
(6.01)\end{array}$ & $\begin{array}{l}0.647 \\
(0.22) * *\end{array}$ & $\begin{array}{l}21.866 \\
(8.33) * *\end{array}$ & $\begin{array}{l}0.123 \\
(1.40)\end{array}$ & $\begin{array}{l}0.414 \\
(6.15)\end{array}$ & $\begin{array}{l}-0.025 \\
(0.11)\end{array}$ & $\begin{array}{l}1.862 \\
(0.21)^{* *}\end{array}$ & $\begin{array}{l}9.392 \\
(6.23)\end{array}$ & $\begin{array}{r}-11.491 \\
(13.45)\end{array}$ \\
\hline Share owners & $\begin{array}{l}66.163 \\
(16.50) * *\end{array}$ & $\begin{array}{l}-4.355 \\
(0.61) * *\end{array}$ & $\begin{array}{l}-184.213 \\
\quad(22.83) * *\end{array}$ & $\begin{array}{l}3.488 \\
(3.84)\end{array}$ & $\begin{array}{r}-8.445 \\
(16.90)\end{array}$ & $\begin{array}{l}1.095 \\
(0.31) * *\end{array}$ & $\begin{array}{l}-9.617 \\
(0.59) * *\end{array}$ & $\begin{array}{l}-115.870 \\
(17.10) * *\end{array}$ & $\begin{array}{r}28.569 \\
(36.97)\end{array}$ \\
\hline Share who feel neighborhood is safe & $\begin{array}{l}-49.925 \\
(17.22) * *\end{array}$ & $\begin{array}{l}4.216 \\
(0.64) * *\end{array}$ & $\begin{array}{l}148.859 \\
(23.82) * *\end{array}$ & $\begin{array}{l}-2.662 \\
(4.00)\end{array}$ & $\begin{array}{r}12.576 \\
(17.63)\end{array}$ & $\begin{array}{l}0.255 \\
(0.32)\end{array}$ & $\begin{array}{l}9.690 \\
(0.61) * *\end{array}$ & $\begin{array}{l}48.419 \\
(17.85) * *\end{array}$ & $\begin{array}{l}-70.213 \\
(38.52)+\end{array}$ \\
\hline Share who feel air pollution is severe & $\begin{array}{l}-47.252 \\
(18.52) *\end{array}$ & $\begin{array}{l}3.692 \\
(0.68) * *\end{array}$ & $\begin{array}{l}131.034 \\
(25.67) * *\end{array}$ & $\begin{array}{r}-3.032 \\
(4.31)\end{array}$ & $\begin{array}{r}6.307 \\
(18.96)\end{array}$ & $\begin{array}{r}-0.055 \\
(0.35)\end{array}$ & $\begin{array}{l}7.996 \\
(0.66) * *\end{array}$ & $\begin{array}{l}48.036 \\
(19.20) *\end{array}$ & $\begin{array}{r}-45.710 \\
(41.41)\end{array}$ \\
\hline
\end{tabular}


Figure A1. Living space

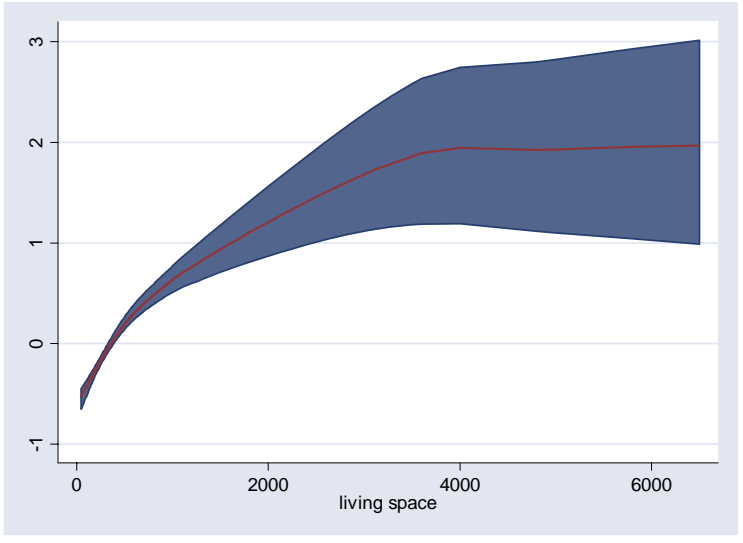

Figure A3. Share houses

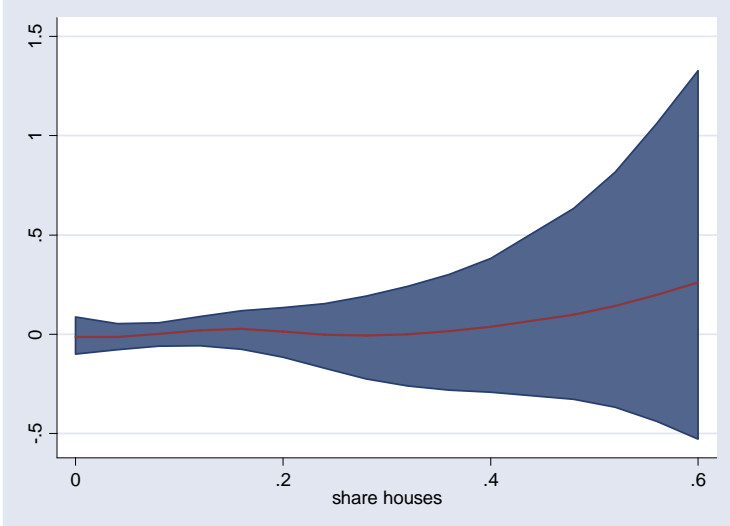

Figure A5. Mean living space

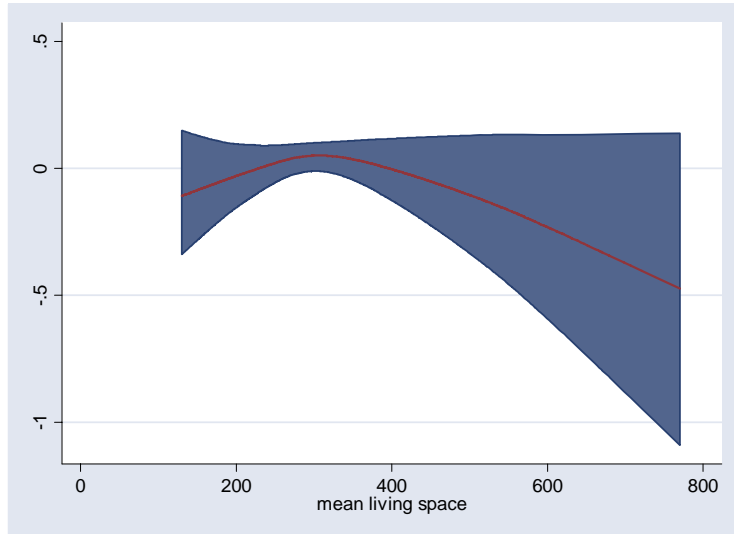

Figure A2. Distance to bus

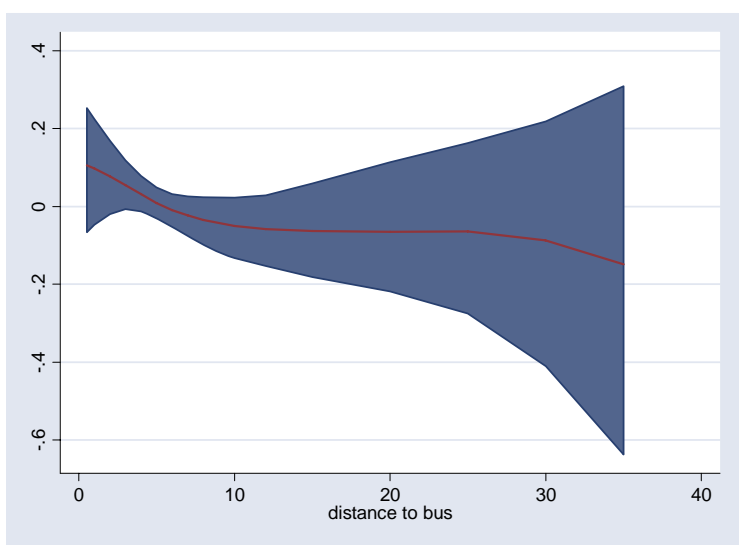

Figure A4. Share attached

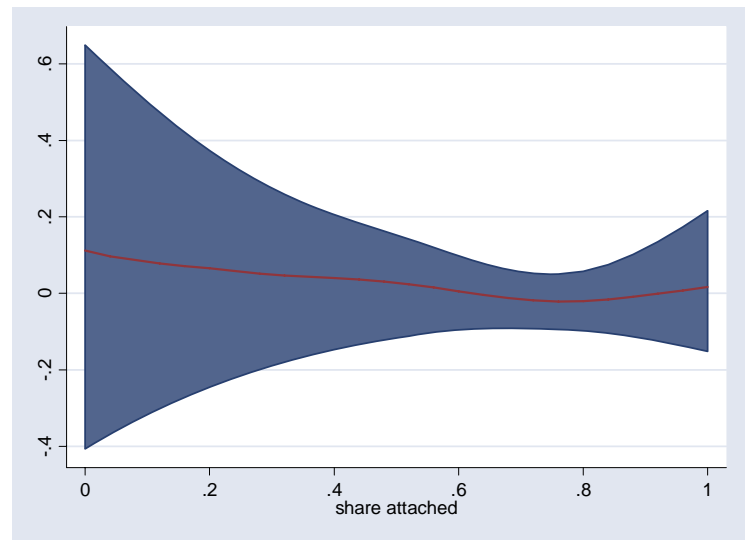

Figure A6. Share with good roof

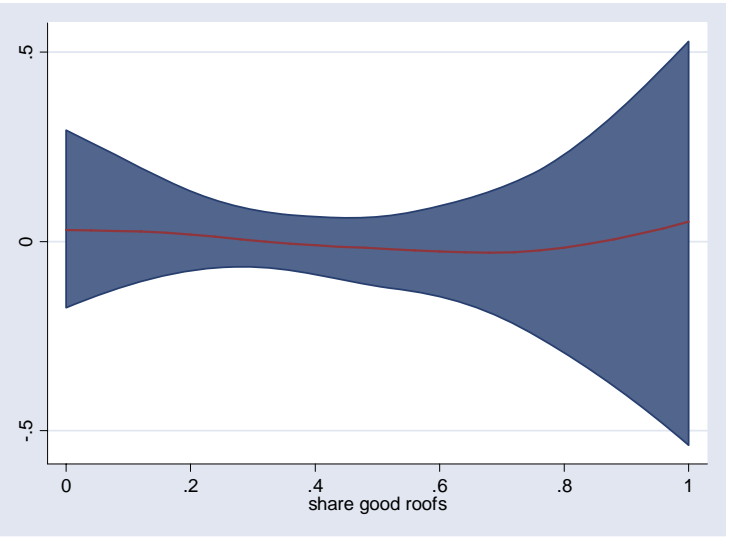


Figure A7. Share with good exterior

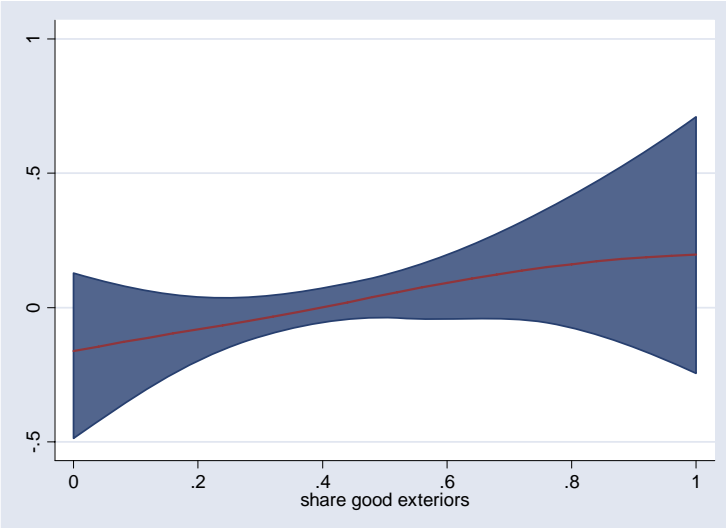

Figure A9. Parks within $1 \mathrm{~km}$

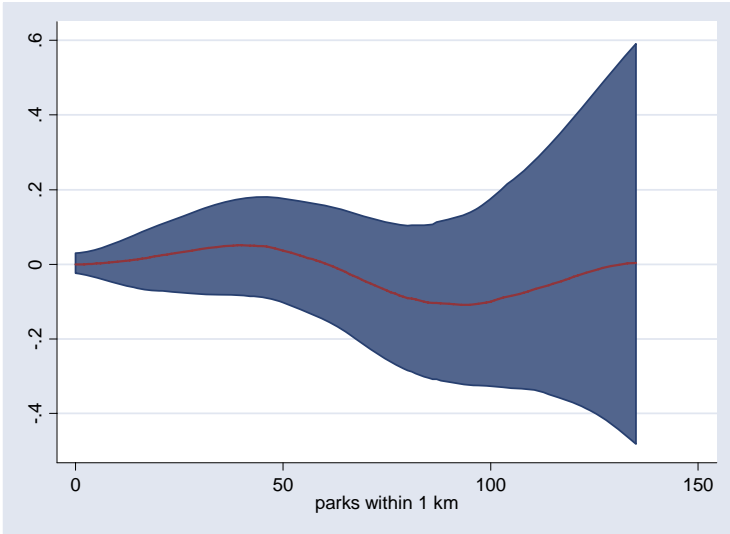

Figure A11. Mean property tax rate

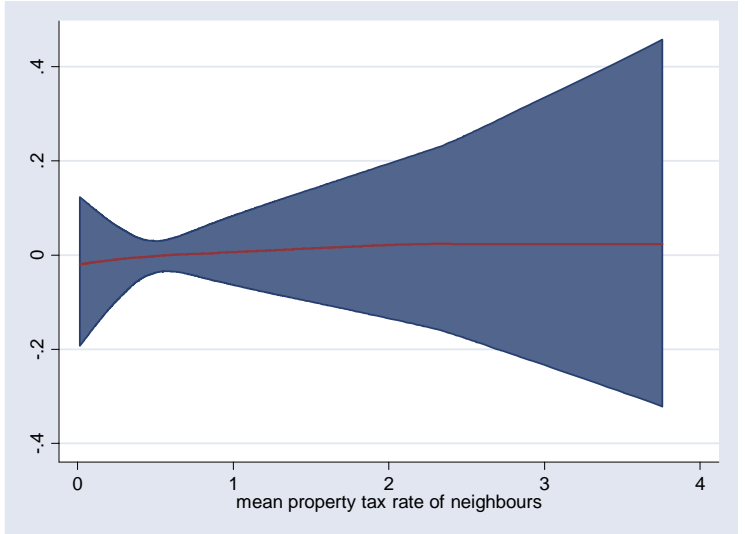

Figure A8. Share slum

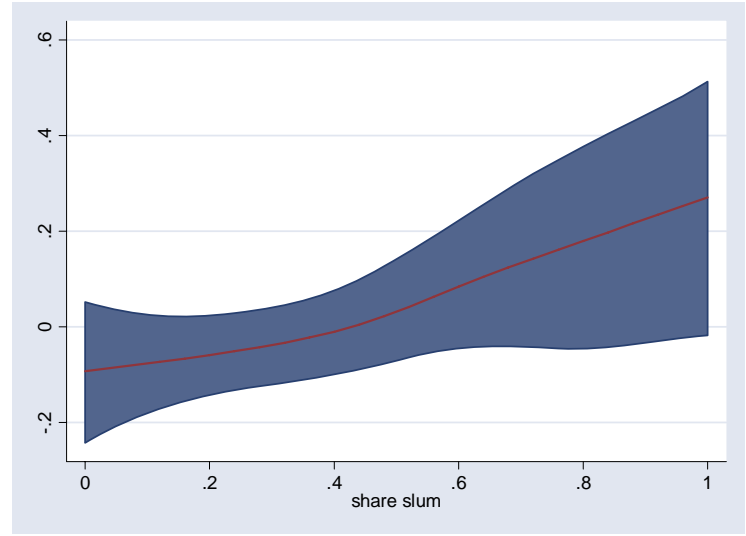

Figure A10. Schools within $1 \mathrm{~km}$

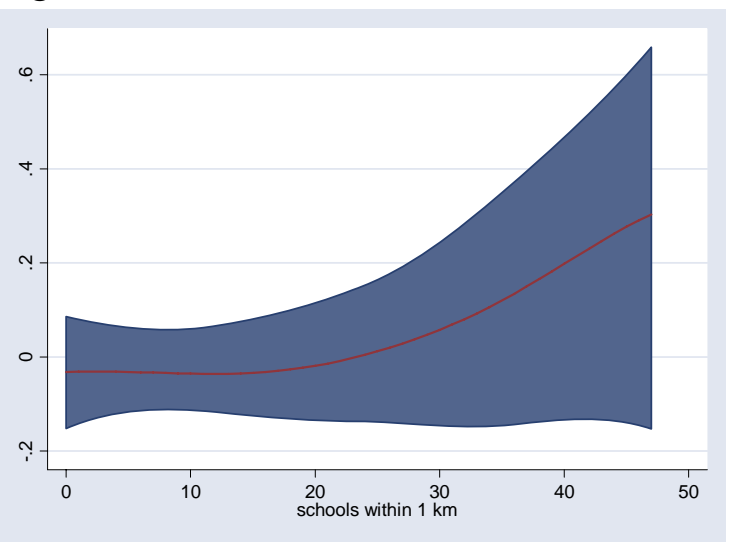

Figure A12. Residential density

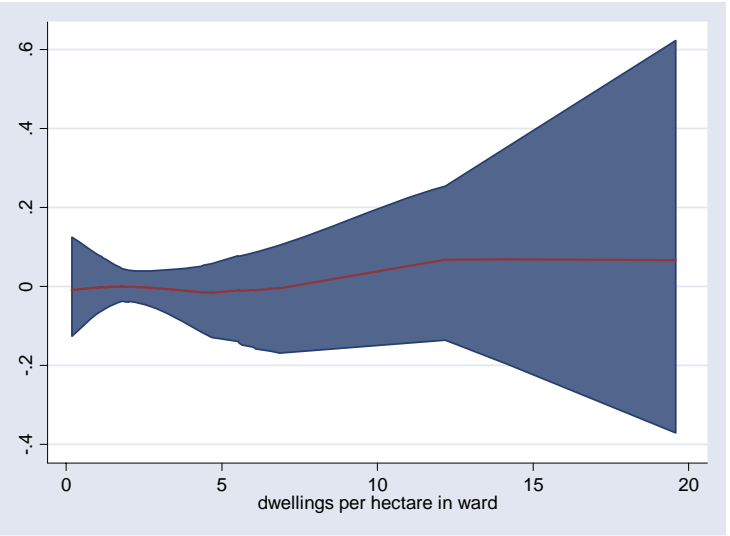


Figure A13. Share scheduled caste

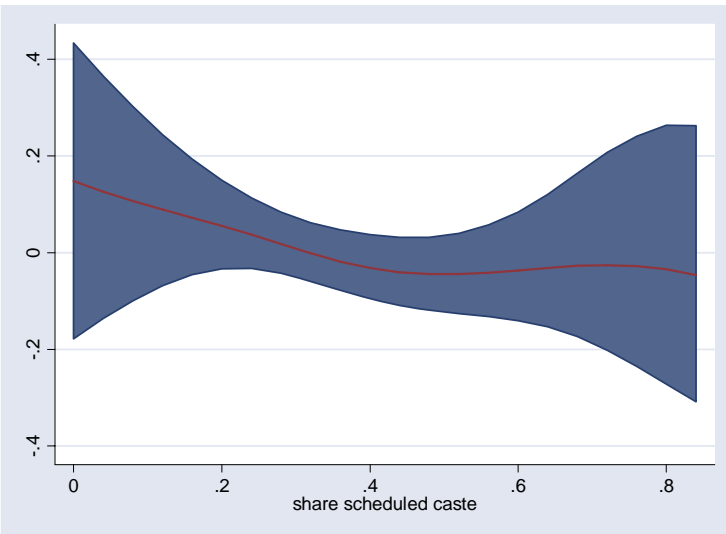

Figure A15. Share with higher education

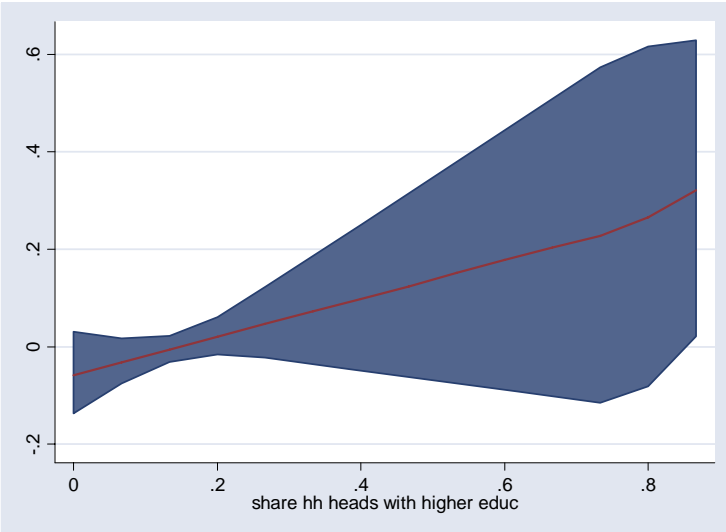

Figure A17. Mean log deviation durables

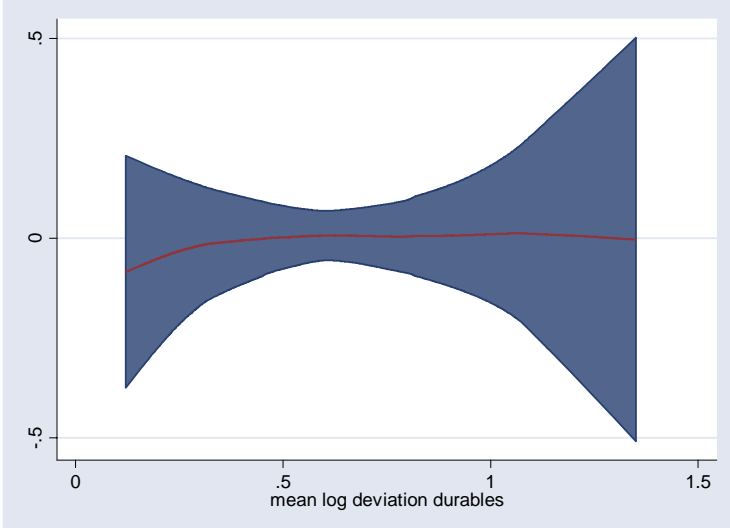

Figure A14. Mean years in dwelling

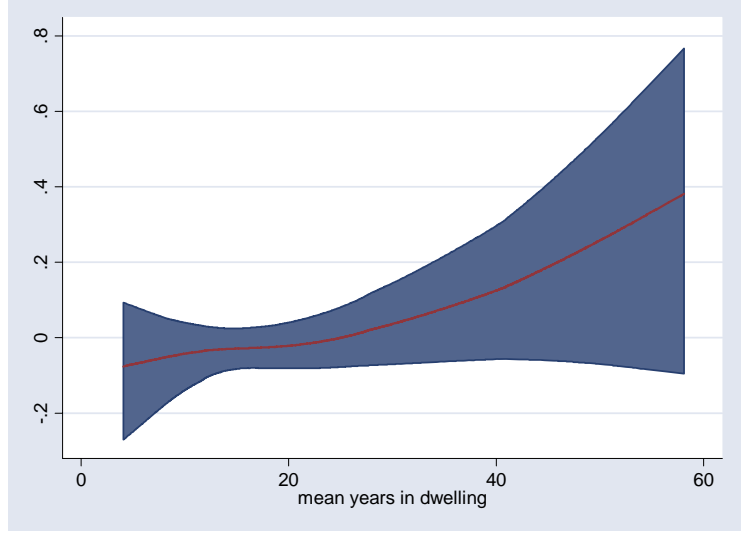

Figure A16. Mean durables income

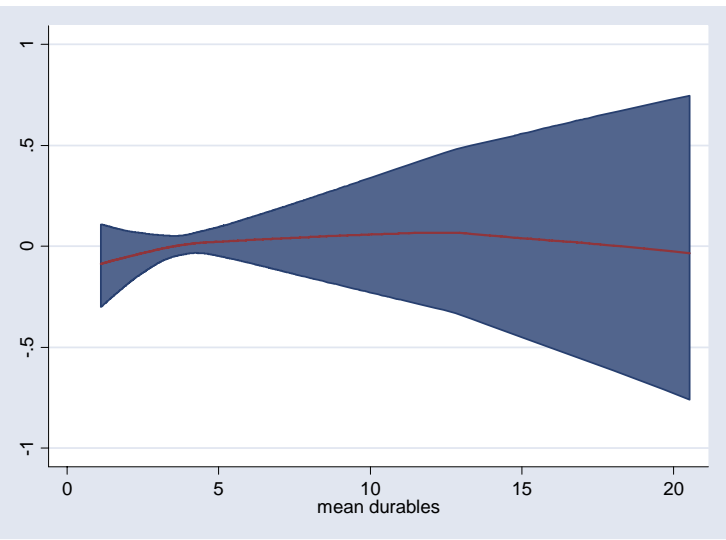

Figure A18. Share owners

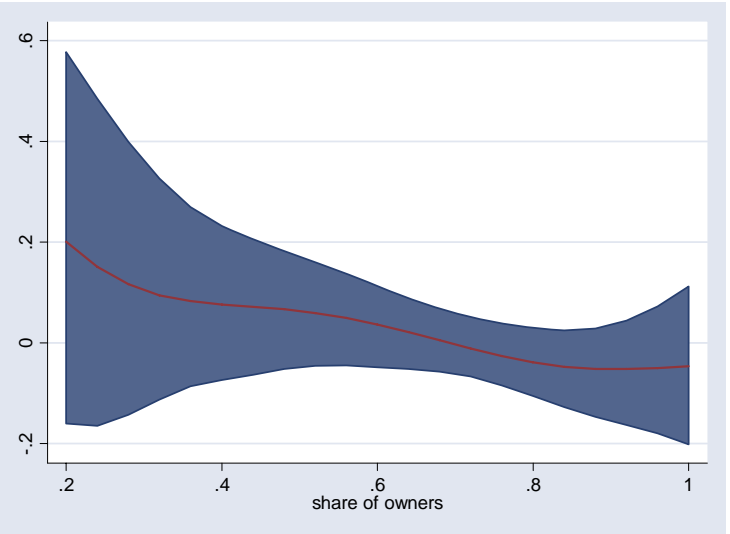


Figure A19. Share who feel safe

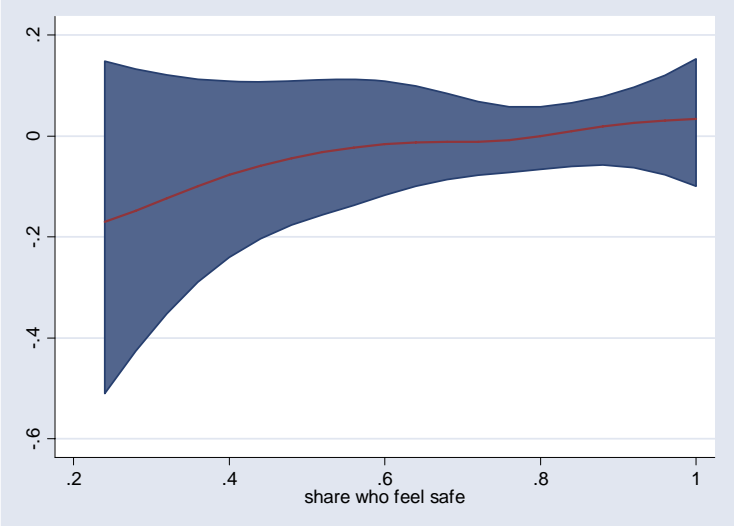

Figure A20. Share who feel roads unsafe

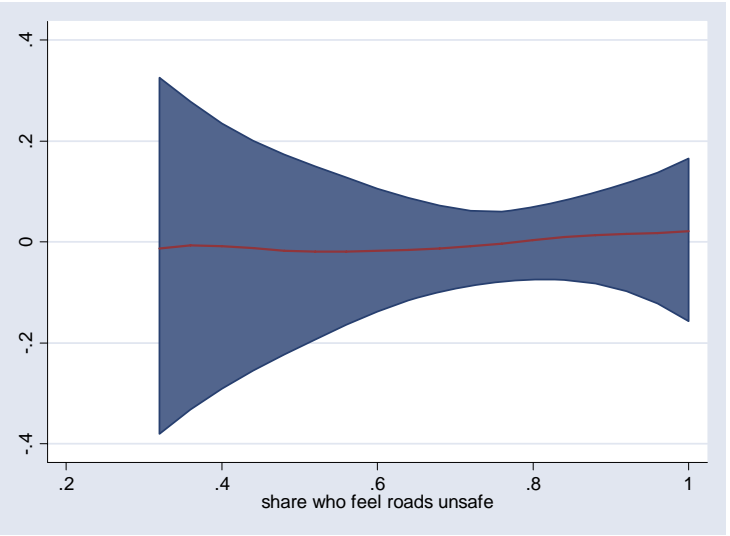

Figure A21. Share who feel air pollution severe

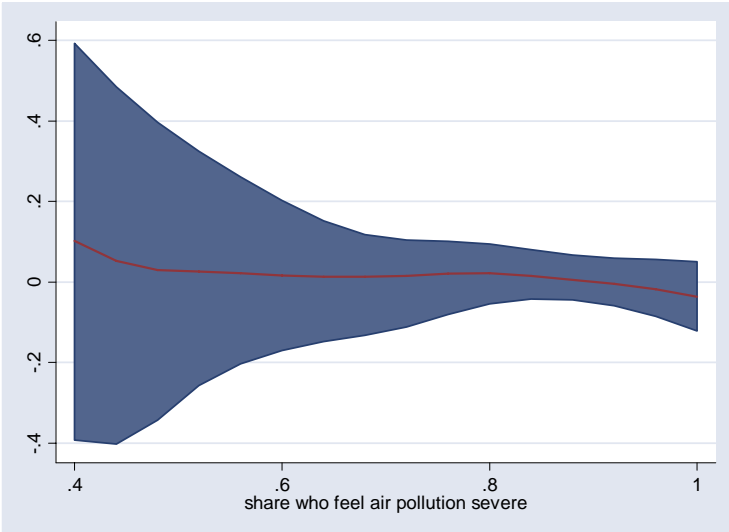

